\title{
PEMANFAATAN ZAKAT ONLINE BAZNAS BAGI MUZAKI
}

Oleh: Decky Hendarsyah

Sekolah Tinggi Ilmu Ekonomi (STIE) Syariah Bengkalis

Email: deckydb@gmail.com

\begin{abstract}
Abstrak
Perkembangan teknologi informasi dan komunikasi saat sekarang sudah tidak terbendung lagi, itu semua dapat dilihat dalam kehidupan nyata sehari-hari. Indonesia termasuk dalam salah satu negara yang terbesar dalam pemanfaatan teknologi informasi dan komunikasi. Itu terbukti, setiap ada produk-produk komunikasi yang baru selalu diserbu oleh masyarakat terutama kalangan menengah ke atas. Kemudian pemerintah Indonesia melalui Kementrian Komunikasi dan Informasi juga sedang gencar-gencarnya mempercepat pembangunan infrastruktur komunikasi dan Internet sampai kepelosokpelosok daerah di seluruh Indonesia. Sehingga hampir semua orang dalam masyarakat sudah mempunyai perangkat elektronik dan komunikasi seperti komputer, televisi, laptop, $P C$-tablet, smartphone dan lain-lain yang terkoneksi ke Internet.

BAZNAS merupakan badan amil zakat nasional yang didirikan oleh pemerintah Indonesia juga tidak mau ketinggalan dalam segi teknologi informasi. Hal itu dibuktikan BAZNAS dengan dibangunnya website sebagai sarana informasi terkini BAZNAS untuk masyarakat dan sistem zakat online untuk para muzaki. Tetapi sampai saat ini pemanfaatan sistem zakat online masih belum banyak diketahui oleh masyarakat di Indonesia. Untuk itu dengan adanya tulisan ini dapat membantu pihak BAZNAS untuk mensosialisasikan sistem zakat onlinenya. Kemudian dalam tulisan ini juga dijelaskan tahap-tahap penggunaan sistem zakat online BAZNAS secara keseluruhan sehingga dapat membantu dan mempermudah muzaki dalam menggunakan zakat online BAZNAS.
\end{abstract}

Kata Kunci: Zakat, Zakat Online, Baznas, Muzaki

\section{A. Latar Belakang}

Zakat adalah kewajiban bagi umat Islam yang mempunyai harta, karena zakat merupakan salah satu dari Rukun Islam. Zakat itu sendiri memiliki hikmah yang dapat dikategorikan dalam dua dimensi yaitu dimensi vertikal dan dimensi horizontal. ${ }^{1}$ Dalam kerangka ini, zakat menjadi perwujudan ibadah seseorang kepada Allah sekaligus sebagai perwujudan dari rasa peduli sosial. ${ }^{2}$

Zakat merupakan pemisahan sejumlah harta tertentu yang diwajibkan oleh Allah SWT. diserahkan untuk umat Islam yang berhak menerimanya. ${ }^{3}$ Kewajiban zakat ini berdasarkan perintah yang ditegaskan Allah dalam Al-qur'an surat At-Taubah ayat $103^{4}$ yang artinya:

"Ambillah zakat dari sebagian harta mereka, dengan zakat itu kamu membersihkan dan mensucikan mereka, dan mendoalah untuk mereka. Sesungguhnya doa kamu

\footnotetext{
${ }^{1}$ Asnani, 2008, “Zakat Produktif Dalam Perspektif Hukum Islam”, Cetakan Pertama, Pustaka Pelajar, Yogyakarta, h.1.

${ }^{2}$ Khadijah, 2012, “Zakat Dalam Sistem Ekonomi Islam Sebuah Alternatif Dalam Meningkatkan Kesejahteraan”, dalam jurnal Iqtishaduna, Vol. 1, No. 1, Juni 2012, Bengkalis, h.137.

${ }^{3}$ Yusuf Qardawi, 2002, "Hukum Zakat”, Cetakan Ketujuh, PT. Pustaka Litera Antarnusa, Jakarta, h. 34-35.

${ }^{4}$ Fitrianto, 2012, "Program Lembaga Amil Zakat (LAZ) Swadaya Ummah Pekanbaru Dalam Membangun Kesejahteraan Umat”, dalam jurnal Iqtishaduna, Vol. 1, No. 1, Juni 2012, Bengkalis, h. 34.
} 
itu (menjadi) ketenteraman jiwa bagi mereka. Dan Allah Maha Mendengar lagi Maha Mengetahui."

Pada masa Rasulullah SAW. Pengelolaan Zakat dilakukan dengan cara pengumpulan zakat perorangan dan membentuk panitia pengumpul zakat. Rasulullah juga menegaskan kepada para pegawainya untuk tidak membedakan dan mempermudah urusan masyarakat dalam tata kelola zakat dengan baik, dengan tidak mementingkan kepentingan sendiri sehingga melupakan hak-hak dan kepentingan fakir dan miskin. ${ }^{5}$

Pada masa sekarang sudah banyak lembaga amil zakat yang didirikan oleh pihakpihak atau kelompok atau organisasi keIslaman maupun pemerintah dalam mengelola zakat. Pemerintah Indonesia sendiri telah mendirikan Badan Amil Zakat Nasional (BAZNAS) yang berada dibawah naungan Kementrian Agama, yang diperuntukan untuk menghimpun, mengelola, mendistribusikan dan mendayanagunakan zakat dari muzaki seluruh Indonesia yang kantornya tersebar mulai dari Kabupaten/Kota, Provinsi dan Pusat.

Tetapi dengan adanya lembaga-lembaga amil zakat, dalam kenyataannya masih ada juga kaum muzaki yang masih mendistribusikan zakatnya langsung kepada pihak mustahik. Ini bisa dilihat pada berita media televisi terutama pada bulan Ramadhan menjelang Idul Fitri. Kaum muzaki membagikan zakat maalnya langsung kepada pihak mustahik atau kaum dhu'afa. Sewaktu pembagian zakat tersebut kebanyakan kaum mustahik tidak tertib kemudian desak-desakan sehingga terjadi dorong-dorongan sesama mustahik dan akhirnya menimbulkan korban jiwa akibat terhimpit dan terjepit, apalagi ada kaum mustahik yang membawa anak balita dan ada juga dari kalangan orang tua renta.

Hal tersebut tentunya sangat disayangkan dan seharusnya tidak boleh terjadi. Oleh karena itu BAZNAS sering menghimbau kepada para pihak muzaki yang ingin menunaikan zakat sebaiknya melalui lembaga-lembaga amil zakat terutama BAZNAS yang kantornya tersebar diseluruh Indonesia. Hal ini dapat memudahkan kaum muzaki tanpa perlu pusing-pusing untuk mengumpulkan para mustahik. Sehingga semua pihak bisa tentram dalam menunaikan dan menerima zakat karena sudah dikelola dan didistribusikan oleh BAZNAS dengan baik, akuntable dan dapat dipercaya.

Apalagi pada saat sekarang dengan adanya perkembangan teknologi informasi dan komunikasi yang semakin cepat dan canggih. Sebagai contoh yaitu dengan adanya media Internet dan munculnya perangkat-perangkat mobile seperti laptop, PC-tablet, smartphone dan sebagainya. Sehingga informasi akan sangat mudah didapat dan transaksi keuangan juga dapat dilakukan oleh semua orang secara online. Oleh sebab itu BAZNAS saat ini sudah menggembangkan sistem penghimpunan zakat melalui media online yaitu menggunakan sistem informasi berbasis Web. Walaupun pihak BAZNAS sudah mensosialisasikan programnya melalui media elektronik, tetapi masih banyak para muzaki di Indonesia belum mengetahui. Untuk itu perlu dibahas mengenai sistem Zakat Online BAZNAS, agar para muzaki mengetahui cara kerja sistem tersebut sehingga sistem tersebut dapat dimanfaatkan para muzaki sebagai salah satu media untuk menyalurkan zakatnya.

\section{B. Teori Tentang Zakat ${ }^{6}$}

\section{Makna Zakat}

Kata Zakat ditinjau dari segi bahasa merupakan kata dasar (masdar) dari zaka yang berarti berkah, tumbuh, bersih dan baik. Sesuatu itu zaka, berarti tumbuh dan berkembang

\footnotetext{
${ }^{5}$ Muhammad, 2002, "Zakat Profesi: Wacana Pemikiran Zakat Dalam Fiqqih Kontemporer", h.17.

${ }^{6}$ Fitrianto, 2012, op.cit., 35-38
} 
dan seorang itu zaka, berarti orang itu baik. Menurut lisan al-Arab arti dasar kata zakat, ditinjau dari sudut bahasa, adalah suci, tumbuh, berkah dan terpuji. ${ }^{7}$ Kesemuan yang menunjukan makna tersebut dapat dijumpai dalam Al-quran ${ }^{8}$ seperti berikut:

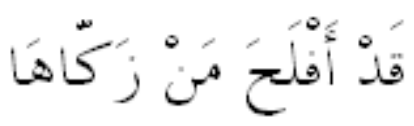

"Sesungguhnya beruntunglah orang yang menyucikan jiwa itu." (QS. AsySyams:9)

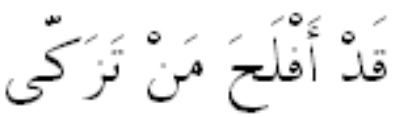

"Sesungguhnya beruntunglah orang yang membersihkan diri (dengan beriman)." (QS. Al-A'laa: 14)

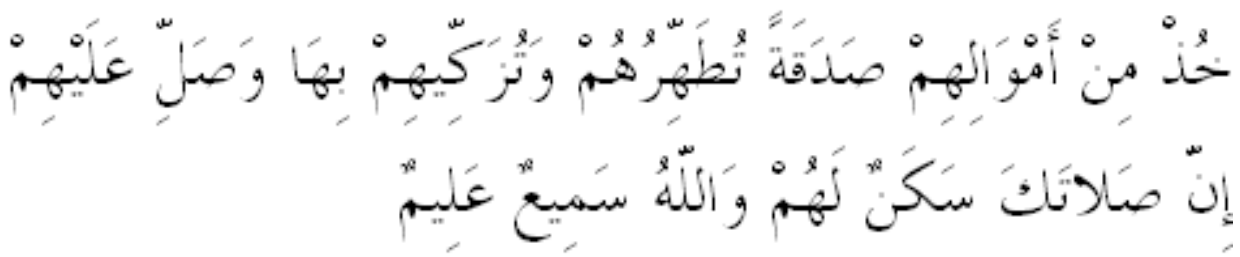

"Ambillah zakat dari sebagian harta mereka, dengan zakat itu kamu membersihkan dan mensucikan mereka, dan mendoalah untuk mereka. Sesungguhnya doa kamu itu (menjadi) ketenteraman jiwa bagi mereka. Dan Allah Maha Mendengar lagi Maha Mengetahui." (QS. At-Taubah: 103)

Mazhab Malikiyah mendifinisikan zakat dengan mengeluarkan sebagian harta yang khusus yang telah mencapai nishab kepada orang-orang yang berhak menerimanya. ${ }^{9}$ Mazhab Hanafiyah mendifinisikan zakat pemberian hak kepemilikan atas sebagian harta tertentu kepada orang tertentu yang telah ditentukan oleh syari'at karena Allah. ${ }^{10}$ Manakala Menurut M. Ali Hasan, ${ }^{11}$ zakat berarti suci, tumbuh dan berkah. Dengan demikian, zakat itu membersihkan (mensucikan) diri seseorang dari hartanya, pahala bertambah, harta tumbuh dan membawa berkat.

Menurut UU. No. 38 tentang Zakat tahun 1999 pada pasal 1 ayat (2) ${ }^{12}$ zakat adalah harta yang wajib disisihkan oleh seorang muslim sesuai dengan ketentuan agama untuk diberikan kepada yang berhak menerimanya. Kemudian menurut UU. No. 23 tentang Zakat tahun 2011 pasal 1 ayat (2) ${ }^{13}$ bahwa Zakat adalah harta yang wajib dikeluarkan oleh seorang muslim atau badan usaha untuk diberikan kepada yang berhak menerimanya sesuai dengan syari'at Islam.

\footnotetext{
${ }^{7}$ Yusuf Qardawi, 2002, op.cit., h. 34-35

${ }^{8}$ Wahbah az-Zuhaili, 2011, Fiqh Islam wa Adillatuhu, Jilid 3, Terjemahan, Gema Insani, h.164.

${ }^{9}$ Wahbah Zuhayliy, "Fiqh Islam wa Adillatuhu”, Jilid 3, Ibid., h. 165.

${ }^{10}$ Wahbah Zuhayliy, Ibid., h. 165.

${ }^{11}$ M. Ali Hasan, 2006, "Zakat dan Infak Salah Satu Solusi Mengatasi Problema Sosial Indonesia”, Edisi 1, Cetakan 1, Kencana Prenada Group, Jakarta, h. 15.

${ }^{12}$ M. Ali Hasan, Ibid., h. 119.

${ }^{13}$ UU. Zakat No. 23, 2011, PDF.
} 


\section{Dasar Hukum Wajibnya Zakat}

Kewajiban zakat merupakan salah satu kewajiban yang harus ditunaikan oleh umat Islam, sebagaimana ditegaskan dalam Al-quran, Hadist dan Ijma'. ${ }^{14}$

a) Al-Qur'an

Dalam Al-Qur'an terdapat 32 kata zakat dan 82 kali diulang dengan menggunakan istilah yang merupakan sinonim dari kata zakat, yaitu kata sedekah dan infak. Pengulangan tersebut mengandung maksud bahwa zakat mempunyai kedudukan, fungsi dan peranan yang sangat penting dalam Islam. ${ }^{15}$ Diantaranya Surah dalam Al-Quran menjelaskan tentang Zakat dan Ancaman bagi yang tidak berzakat yaitu: At-Taubah 34-35 dan 103: ${ }^{.6}$

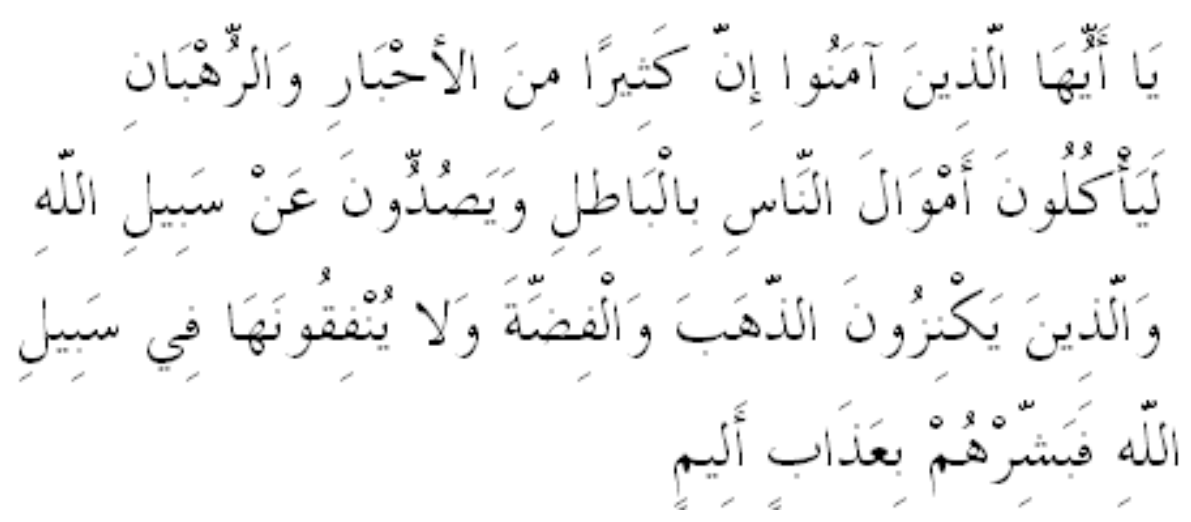

"Hai orang-orang yang beriman, sesungguhnya sebahagian besar dari orangorang alim Yahudi dan rahib-rahib Nasrani benar-benar memakan harta orang dengan jalan yang batil dan mereka menghalang-halangi (manusia) dari jalan Allah. Dan orang-orang yang menyimpan emas dan perak dan tidak menafkahkannya pada jalan Allah, maka beritahukanlah kepada mereka, (bahwa mereka akan mendapat) siksa yang pedih.” (QS. At-Taubah: 34)

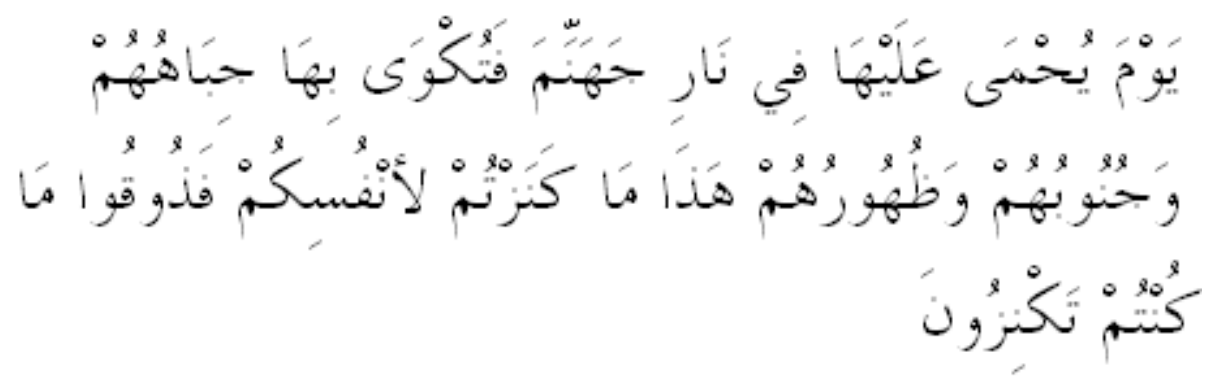

"Pada hari dipanaskan emas perak itu dalam neraka Jahanam, lalu dibakar dengannya dahi mereka, lambung dan punggung mereka (lalu dikatakan) kepada mereka: "Inilah harta bendamu yang kamu simpan untuk dirimu sendiri, maka rasakanlah sekarang (akibat dari) apa yang kamu simpan itu”.” (QS. AtTaubah:35)

\footnotetext{
${ }^{14}$ Nurdin M. Ali, 2006, “Zakat Sebagai Instrumen Dalam Kebijakan Fiskal”, PT. Raja Grafindo Persada, Jakarta, h. 24.

${ }^{15}$ Abdurrahman Qadir, 1998, "Zakat Dalam Dimensi Mahdah dan Sosial”, PT. Raja Grafindo Persada, Jakarta, h. 43.

${ }^{16}$ Departemen Agama, 1998, “Alquran dan Terjemahan”, CV-Atlas, Jakarta, h. 283.
} 


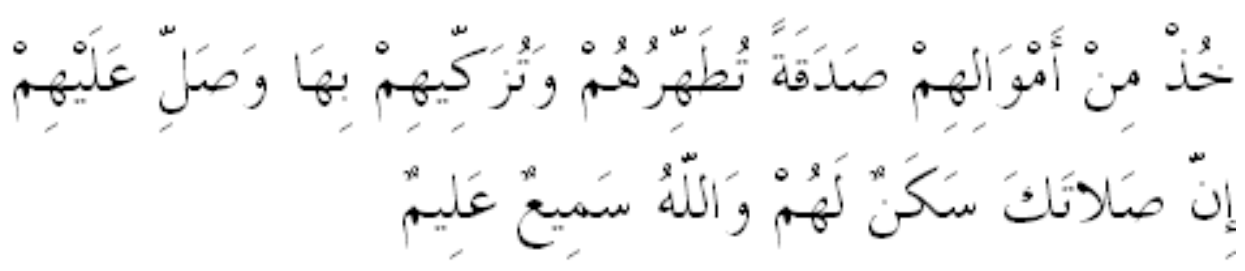

"Ambillah zakat dari sebagian harta mereka, dengan zakat itu kamu membersihkan dan mensucikan mereka, dan mendoalah untuk mereka. Sesungguhnya doa kamu itu (menjadi) ketenteraman jiwa bagi mereka. Dan Allah Maha Mendengar lagi Maha Mengetahui." (QS. At-Taubah: 103)

b) Al-Hadist

Sabda Rasulullah yang artinya: diriwayatkan dari Ibnu Umar r.a. sesungguhnya Rasulullah SAW bersabda: "Islam itu dibina di atas lima pilar (dasar): ... diantaranya, menunaikan zakat". ${ }^{17}$

Salah satu hadist yang diriwayatkan oleh Bukhari dan Muslim dari pada Abu Hurairah r.a., bahwa Rasulullah SAW bersabda yang artinya:

"Barang siapa yang diberikan Allah harta tetapi tidak mengeluarkan zakatnya, maka hartanya itu akan dirupakan pada hari kiamat sebagai seekor ular jantan yang amat berbisa, dengan kedua matanya yang dilindungi dengan mata hitam yang kelam lalu dikalungkan dilehernya, maka ular itu akan memegang rahangnya dan mengatakan padanya "saya ini adalah simpananmu harta kekayaanmu”, kemudian Rasulullah membaca ayat yang artinya janganlah orang-orang yang kikir sekali dengan karunia yang diberikan Allah kepada mereka itu, mengira bahwa tindakannya itu baik bagi mereka. Tidak, tetapi buruk bagi mereka, segala yang mereka kikirkan itu dikalungkan di leher mereka pada hari kiamat" (Riwayat Bukhari dan Muslim). ${ }^{18}$

c) Dalil Ijma'

Setelah Nabi Muhammad SAW. wafat, maka pemimpin pemerintahan dipegang oleh Abu Bakar Shiddiq yang selanjutnya dinobatkan sebagai khalifah pertama. Pada masa kepemimpinannya timbul gerakan sekelompok orang yang menolak membayar zakat (Mani' Al-Zakah) kepada khalifah pertama. Abu Bakar mengajak para sahabat bermufakat untuk memantapkan pelaksanaan dan penerapan zakat, serta mengambil tindakan tegas untuk menumpas orang-orang yang menolak membayar zakat dengan mengkategorikan mereka sebagai orang Murtad. Seterusnya pada masa Tabi'in dan Imam Mujtahid serta murid-murid mereka dilakukan Ijtihad untuk merumuskan pola operasional zakat sesuai dengan situasi dan kondisi ketika itu. ${ }^{19}$

\section{Macam Zakat Dalam Islam}

\footnotetext{
${ }^{17}$ Wahbah Zuhayliy, op.cit., h. 168.

${ }^{18}$ Wahbah Zuhayliy, op.cit., h. 169.

${ }^{19}$ Nurdin M. Ali, op.cit, h. 27.
} 
Zakat dalam Islam terbagi dua bentuk yaitu pertama zakat fitrah ${ }^{20}$ merupakan kewajiban bagi umat Islam pada bulan Ramadhan baik anak-anak maupun orang tua mengeluarkan $2,5 \mathrm{~kg}$ dari makanan pokok untuk dibagikan kepada mustahik. Selain itu kewajiban zakat fitrah itu, berfungsi untuk menutupi kekurangan puasa Ramadhan dan mencukupi orang-orang fakir dari meminta pada hari raya idul fitri. ${ }^{21}$ Kedua zakat harta (Al-Maal).

\section{Syarat-Syarat Dan Rukun Wajib Zakat ${ }^{22}$}

Adapun syarat-syarat wajib zakat adalah: muslim, aqil, baligh, harta milik sempurna, cukup nisab dan cukup haul, berkembang, lebih dari kebutuhan pokok (Alhajatul Ashliyah) dan bebas dari hutang.

\section{Orang Yang Berhak Menerima Zakat (Mustahik)}

Pendistribusian harta zakat kepada asnab delapan sebagaimana dijelaskan dalam Al-Quran surat At-Taubah: 60, yaitu: ${ }^{23}$ fakir, miskin, mu'allaf, riqab (budak), gharimin (orang yang berhutang), fisabilillah dan ibnu sabil.

\section{Sistem Online}

Sistem adalah suatu jaringan kerja yang saling berhubungan dalam melakukan suatu kegiatan tertentu secara bersama. Online dapat diartikan terhubung atau terkoneksi dan siap untuk beroperasi dan dapat berkomunikasi dengan komputer atau perangkat elektronik lainnya melalui media Internet. Sehingga dapat disimpulkan bahwa sistem online adalah suatu kegiatan yang saling terhubung menggunakan komputer ataupun perangkat elektronik melalui media Internet yang bertujuan untuk mencapai tujuan bersama.

Dalam sistem online untuk melihat atau mengakses informasi ataupun bertransaksi sering menggunakan website yang diakses melalui web browser. Kemudian dalam sistem online untuk melakukan transaksi keuangan perbankan salah satunya menggunakan fasilitas internet banking melalui website. Jadi kedua hal tersebut sangat erat kaitannya dalam pemanfaatan zakat online.

\section{Website}

Website atau situs web adalah sejumlah halaman web yang memiliki topik saling terkait, terkadang disertai pula dengan berkas-berkas gambar, video atau jenis-jenis berkas lainnya. Sebuah situs biasanya ditempatkan setidaknya pada sebuah server web yang dapat diakses melalui jaringan seperti Internet ataupun jaringan lokal (Local Area Network) melalui alamat web. Sedangkan gabungan atas semua situs yang dapat diakses publik di Internet disebut dengan www (world wide web).

\section{Internet Banking ${ }^{24}$}

Internet Banking secara ringkas dapat diartikan sebagai aktifitas perbankan di Internet. Pengertian Internet Banking dapat didefinisikan sebagai berikut:

\footnotetext{
${ }^{20}$ Heri Sudarsono, 2003, “Bank dan Lembaga Keuangan Syariah, Deskripsi dan Ilustrasi”, Edisi II, Cetakan III, Ekonosia, Yogyakarta, h. 233.

${ }^{21}$ Wahbah Zuhayliy, op.cit., h. 346-347.

${ }^{22}$ Wahbah Zuhayliy, op.cit., h. 170-174.

${ }^{23}$ Yusuf Qardawi, op.cit., h. 507-508 dan M. Ali Hasan, op.cit., h. 90-91.

${ }^{24}$ Decky Hendarsyah, 2012, "Keamanan Layanan Internet Banking Dalam Transaksi Perbankan", dalam jurnal Iqtishaduna, Vol. 1, No. 1, Juni 2012, Bengkalis, h. 13.
} 
a) Menurut David Whiteley ${ }^{25}$ :

"Internet Banking adalah salah satu jasa pelayanan yang diberikan bank kepada nasabahnya dengan maksud agar nasabah dapat mengecek saldo rekening dan membayar tagihan selama 24 jam tanpa perlu datang ke kantor cabang".

b) Menurut Mary J. Cronin ${ }^{26}$ :

"Internet Banking adalah aplikasi layanan keuangan yang memungkinkan lembaga keuangan untuk menawarkan produk dan layanan perbankan tradisionalnya seperti cek saldo tabungan dan rekening pasar uang serta sertifikat deposito melalui Internet".

c) Menurut Mahmood Shah dan Steve Clarke ${ }^{27}$ :

"Penyediaan informasi mengenai bank dan layanannya melalui halaman website di World Wide Web (WWW). Dimana layanan yang disediakan berupa akses pelanggan ke rekening, dapat mentransfer antar rekening yang berbeda dan dapat melakukan pembayaran atau mengajukan pinjaman melalui channel elektronik".

\section{Produk Zakat Maal (Harta)}

Produk zakat maal (harta) dapat dikelompokan sebagai berikut:

\section{Zakat Peternakan ${ }^{28}$}

Zakat Hasil Ternak (salah satu jenis zakat maal) meliputi hasil dari peternakan hewan baik besar (sapi dan unta) sedang (kambing dan domba) dan kecil (unggas dan lainlain). Perhitungan zakat untuk masing-masing tipe hewan ternak, baik nisab maupun kadarnya berbeda-beda dan sifatnya bertingkat. Sedangkan haulnya yakni satu tahun untuk tiap hewan.

a) Syarat Umum:

- Sampai nishab.

- Berlalu satu tahun.

- Tenaganya tidak dipergunakan untuk produksi.

- Digembalakan.

b) Nishab dan kadar zakat atas unta adalah sebagai berikut:

- 1 sampai 4 ekor tidak ada zakat

- 5 sampai 9 ekor seekor kambing

- 10 sampai 14 ekor dua ekor kambing

- 15 sampai 19 ekor tiga ekor kambing

- 20 sampai 24 ekor empat ekor kambing

- 25 sampai 35 ekor seekor unta betina 1 tahun

- 36 sampai 45 ekor seekor unta betina 2 tahun

- 46 sampai 60 ekor seekor unta betina 3 tahun

- 61 sampai 75 ekor seekor unta betina 4 tahun

- 76 sampai 90 ekor 2 ekor unta betina 2 tahun

- 91 sampai 120 ekor 2 ekor unta betina 3 tahun

- Setiap tambahan 50 unta seekor unta 3 tahun dan tambahan 40 unta seekor unta 2 tahun.

c) Nishab dan kadar zakat atas sapi adalah sebagai berikut:

\footnotetext{
${ }^{25}$ David Whiteley, 2000, E-Commerce: Strategy, Technologies And Applications, London: MC. Graw-Hill. h. 229.

${ }^{26}$ Mary J. Cronin, 1998, Banking and Finance on the Internet, Canada: John Wiley \& Sons, h. 7.

${ }^{27}$ Mahmood Shah dan Steve Clarke, 2009, E-Banking Management: Issue, Solutions and Strategies, London: IGI Global. h. 2 .

${ }^{28}$ http://pusat.baznas.go.id/zakat-peternakan/ diakses tanggal 29 Nopember 2013
} 
- 1 sampai 29 ekor tidak ada zakat

- 30 sampai 39 ekor seekor anak sapi

- 40 sampai 59 ekor seekor sapi satu tahun

- 60 sampai 69 ekor seekor sapi usia 2 tahun

- 70 sampai 79 ekor 2 ekor anak sapi

- 80 sampai 89 ekor seekor anak sapi \& sapi 2 thn

- 90 sampai 99 ekor 2 ekor sapi 2 tahun

- 100 sampai 109 ekor 3 ekor anak sapi

- 110 sampai 119 ekor 2 ekor anak sapi \& seekor sapi usia 2 tahun

- Kemudian setiap pertambahan 30 ekor seekor anak sapi dan pertambahan 40 ekor seekor sapi usia 2 tahun.

\section{Zakat Pertanian ${ }^{29}$}

a) Nishab dan Tarif:

Dari Jabir, dari Rasulullah SAW. "Tidak wajib bayar zakat pada kurma yang kurang dari 5 ausuqâ". (HR. Muslim):

- Dari hadist ini dijelaskan bahwa nishab zakat pertanian adalah 5 ausuq;

- Ausuq jamak dari wasaq, 1 wasaq = 60 sha', sedangkan 1 sha' = 2,176 kg, maka 5 wasaq adalah $5 \times 60 \times 2,176=652,8 \mathrm{~kg}$.

Kadar zakat yang harus dikeluarkan:

- jika diairi oleh hujan atau sungai $10 \%$, dan

- jika diairi oleh pengairan $5 \%$

Zakat pertanian dikeluarkan saat menerima hasil panen.

b) Syarat zakat pertanian:

- Islam

- Merdeka

- Sempurna milik

- Cukup nisab

- Tanaman tersebut adalah makanan asasi yang tahan disimpan lama.

- Tanaman tersebut adalah hasil usaha manusia dan bukannya tumbuh sendiri seperti tumbuh liar, dihanyutkan air dan sebagainya.

c) Nishab hasil bumi yang tidak diliter:

- Nishab 5 ausuq adalah bagi hasil bumi yang dapat diukur dengan takaran tersebut.

- Adapun bagi hasil bumi yang tidak dapat diliter, menurut Dr. Yusuf Qordhowi, nishabnya sama dengan nilai $653 \mathrm{~kg}$ hasil bumi yang berharga (seperti padi atau gandum).

\section{Zakat Emas, Perak dan Uang ${ }^{30}$}

a) Kategori Zakat Emas dan Perak:

Harta lain yang juga termasuk kategori emas dan perak:

- Logam atau batu mulia dan mata uang.

- Simpanan seperti: tabungan, deposito, cek atau surat berharga lainnya.

b) Syarat Zakat Emas \& Perak:

- Sampai nishab.

- Berlalu satu tahun.

\footnotetext{
${ }^{29} \mathrm{http}: / /$ pusat.baznas.go.id/zakat-pertanian/ diakses tanggal 29 Nopember 2013

${ }^{30} \mathrm{http}$ ://pusat.baznas.go.id/zakat-emas-perak-dan-uang/ diakses tanggal 29 Nopember 2013
} 
- Bebas dari hutang yang menyebabkan kurang dari nishab.

- Surplus dari kebutuhannya.

- Jika perhiasan tersebut sebagai simpanan atau investasi, wajib dikeluarkan zakatnya $2.5 \%$ dengan syarat nishab dan haul.

- Perhiasan yang haram digunakan dan terbuat dari emas dan perak, wajib dikeluarkan zakatnya.

- Jika perhiasan tersebut untuk dipakai dan dalam batas yang wajar, tidak dikenakan zakat, jika berlebihan termasuk katagori pertama.

- Penentuan nishabnya adalah senilai dengan nishab emas 85 gram.

c) Nishab dan kadar zakat emas, perak dan uang:

- Nishab emas 20 dinar, 1 dinar = 4,25 gram, maka nishab emas adalah 20 x 4,25 gram $=85$ gram.

- Nishab Perak adalah 200 dirham, 1 dirham = 2,975 gram, maka nishab perak adalah $200 \times 2,975$ gram $=595$ gram.

- Demikian juga macam jenis harta yang merupakan harta simpanan dan dapat dikategorikan dalam emas dan perak, seperti uang tunai, tabungan, cek, saham, surat berharga ataupun bentuk lainnya. Maka nishab dan zakatnya sama dengan ketentuan emas dan perak. Artinya jika seseorang memiliki bermacam-macam bentuk harta dan jumlah akumulasinya lebih besar atau sama dengan nishab (85 gram emas) maka ia telah terkena kewajiban zakat $(2.5 \%)$.

\section{Zakat Atas Madu ${ }^{31}$}

a) Nishab dan tarif zakat madu:

- Imam Abu Hanifah tidak menetapkan nishab madu dan menetapkan tarifnya $10 \%$.

- Imam Ahmad menentukan nishabnya sebanyak 16 liter Bagdadi.

- Sebagian Ulama menganalogikan pada hasil pertanian maka nishabnya adalah senilai $652,8 \mathrm{~kg}$ sedangkan tarifnya $10 \%$ jika terdapat di tanah yang datar dan $5 \%$ jika berada di pegunungan.

b) Kadar zakat madu:

Para ulama bersepakat bahwa zakat madu diambil dari pendapatan bersih madu, atau setelah dikurangi dari biaya-biaya untuk mendapatkannya dan besarnya sepersepuluh $(10 \%)$.

c) Zakat atas hasil produksi hewani:

- Zakat atas produk hewani seperti harus diperlakukan sama dengan madu.

- Hal ini berlaku pula pada ternak-ternak piaraan yang memang khusus diambil susunya dan tidak merupakan barang dagangan.

- Zakat atas produk hewani adalah sebesar sepersepuluh dari penghasilan bersih, atau setelah dikurangi biaya-biaya.

- Diantara ulama fiqh ada pula yang berpendapat jika seseorang yang membeli hewan untuk dijual produknya, misalnya sapi untuk dijual susunya, ulat sutera untuk dijual suteranya, atau sejenisnya; maka orang itu harus menghitung nilai benda-benda tersebut dengan produknya pada akhir tahun, lalu mengeluarkan zakatnya seperti zakat perniagaan $(2,5 \%)$.

\section{Zakat Investasi ${ }^{32}$}

\footnotetext{
${ }^{31} \mathrm{http}: / /$ pusat.baznas.go.id/zakat-atas-madu/ diakses tanggal 29 Nopember 2013

${ }^{32} \mathrm{http}: / /$ pusat.baznas.go.id/zakat-investasi/ diakses tanggal 29 Nopember 2013
} 
Zakat investasi dalam istilah fiqh biasa disebut zakat "Almustaghillat". Zakat tersebut dikenakan terhadap harta yang diperoleh dari hasil investasi. Diantara bentuk usaha yang termasuk investasi adalah; bangunan atau kantor yang disewakan, saham, rental mobil, rumah kontrakan, dan lain-lain. Sebagian ulama Hanbali menganalogikan ke dalam zakat perdagangan, dengan tarif $2,5 \%$ dan nishab 85 gram serta sampai haul. Analogi zakat investasi:

a) Sebagian ulama Maliki dan Salaf seperti Ibnu Masud, Ibnu Abbas, dan lain-lain menganalogikannya ke dalam zakat uang tapi diambil dari hasilnya saja, tanpa mensyaratkan haul dikeluarkan ketika menerimanya.

b) Para ulama kontemporer, seperti Abu Zahrah, Abdul Wahab Kholaf, dan Yusuf Qordhowi, menganalogikannya ke dalam zakat pertanian yaitu dikeluarkan saat menghasilkan dari hasilnya, tanpa memasukkan unsur modal dengan tarif 5\% untuk penghasilan kotor dan $10 \%$ untuk penghasilan bersih.

\section{Zakat Perniagaan ${ }^{33}$}

Ulama-ulama fikih menamakan zakat perniagaan dengan istilah "Harta Benda Perdagangan" (Arudz al Tijaroh), yakni: Semua yang diperuntukkan untuk dijual selain uang kontan dalam berbagai jenisnya, meliputi alat-alat, barang-barang, pakaian, makanan, perhiasan, binatang, tumbuhan, tanah, rumah, dan barang-barang tidak bergerak maupun bergerak lainnya.

a) Ketentuan zakat perniagaan:

- Berlalu masanya setahun

- Mencapai nishab 85 gr emas

- Bebas dari hutang

- Kadar zakat yang dikeluarkan adalah 2,5\%

- Dapat dibayarkan dengan uang atau barang

b) Cara Perhitungan:

(Modal+Keuntungan+Piutang) - (Hutang+Kerugian) x 2,5\%

\section{Zakat Harta Galian ${ }^{34}$}

Dari Abu Hurairah, bahwa Rasulullah SAW pernah bersabda: "Pada rikaz harta galian, zakatnya seperlima (20\%)". (HR Bukhori Muslim).

a) Zakat rikaz berbeda dengan zakat barang tambang.

b) Zakat barang tambang mencakup semua jenis, baik padat maupun cair.

c) Zakat rikaz dan barang tambang tidak mensyaratkan nishab dan haul.

d) Tarif zakat rikaz 20\% dan zakat barang tambang 2,5\% kecuali ada kemiripan.

e) Mustahik zakat rikaz dan barang tambang sama dengan mustahikkin zakat lainnya.

\section{Zakat Profesi ${ }^{35}$}

Zakat profesi adalah zakat atas penghasilan yang diperoleh dari pengembangan potensi diri yang dimiliki seseorang dengan cara yang sesuai syariat, seperti upah kerja rutin, profesi dokter, pengacara, arsitek dan lain-lain.

Dari berbagai pendapat dinyatakan bahwa landasan zakat profesi dianalogikan kepada zakat hasil pertanian yaitu dibayarkan ketika mendapatkan hasilnya, demikian juga dengan nishabnya yaitu sebesar $524 \mathrm{~kg}$ makanan pokok, dan dibayarkan dari pendapatan

\footnotetext{
${ }^{33} \mathrm{http} / / /$ pusat.baznas.go.id/zakat-perniagaan/ diakses tanggal 29 Nopember 2013

${ }^{34} \mathrm{http} / / /$ pusat.baznas.go.id/zakat-harta-galian/ diakses tanggal 29 Nopember 2013

${ }^{35} \mathrm{http}$ ///pusat.baznas.go.id/produk/zakat-profesi/ diakses tanggal 29 Nopember 2013
} 
kotor. Sedangkan tarifnya adalah dianalogikan kepada zakat emas dan perak yaitu sebesar 2,5\%, atas dasar kaidah "Qias Asysyabah".

\section{Zakat Saham dan Obligasi ${ }^{36}$}

Zakat yang wajib dikeluarkan atas kepemilikan surat berharga, termasuk diantaranya obligasi, reksadana dan saham bursa efek.

a) Periode haul: setelah dimiliki 1 tahun.

b) Nisab : 85 gram emas.

c) Zakat yang dikeluarkan sebesar $2,5 \%$ dari total nilai bruto.

\section{E. Profil BAZNAS ${ }^{37}$}

Badan Amil Zakat Nasional (BAZNAS) merupakan badan resmi dan satu-satunya yang dibentuk oleh pemerintah berdasarkan Keputusan Presiden RI No. 8 Tahun 2001 yang memiliki tugas dan fungsi menghimpun dan menyalurkan zakat, infaq, dan sedekah (ZIS) pada tingkat nasional. Lahirnya Undang-Undang Nomor 23 Tahun 2011 tentang Pengelolaan Zakat semakin mengukuhkan peran BAZNAS sebagailembaga yang berwenang melakukan pengelolaan zakat secara nasional.

Dalam UU tersebut, BAZNAS dinyatakan sebagai lembaga pemerintah nonstruktural yang bersifat mandiri dan bertanggung jawab kepada Presiden melalui Menteri Agama. Dengan demikian, BAZNAS bersama Pemerintah bertanggung jawab untuk mengawal pengelolaan zakat yang berasaskan: syariat Islam, amanah, kemanfaatan, keadilan, kepastian hukum, terintegrasi dan akuntabilitas.

1. BAZNAS menjalankan empat fungsi, yaitu:

a) Perencanaan pengumpulan, pendistribusian, dan pendayagunaan zakat;

b) Pelaksanaan pengumpulan, pendistribusian, dan pendayagunaan zakat;

c) Pengendalian pengumpulan, pendistribusian, dan pendayagunaan zakat; dan

d) Pelaporan dan pertanggungjawaban pelaksanaan pengelolaan zakat.

2. BAZNAS memiliki kewenangan:

a) Menghimpun, mendistribusikan, dan mendayagunakan zakat.

b) Memberikan rekomendasi dalam pembentukan BAZNAS Provinsi, BAZNAS Kabupaten/Kota, dan LAZ

c) Meminta laporan pelaksanaan pengelolaan zakat, infak, sedekah, dan dana sosial keagamaan lainnya kepada BAZNAS Provinsi dan LAZ.

\section{F. Program BAZNAS}

Program-program yang telah dilaksanakan oleh BAZNAS sampai saat sekarang adalah sebagai berikut:

1. Zakat Community Development:

Adalah proses jangka panjang dengan mengintegrasikan program-program untuk mengatasi masalah kesehatan, pendidikan, ekonomi dan masalah sosial, dengan menggunakan dana Zakat Infak Shodaqoh.

2. Konter Layanan Mustahik:

Adalah tempat pelayanan mustahik yang dibentuk BAZNAS untuk memudahkan mustahik mendapatkan bantuan sesuai kebutuhannya.

3. Rumah Sehat BAZNAS:

Adalah Program Layanan Kesehatan cuma-cuma bagi masyarakat miskin, sering disebut juga sebagai "Rumah Sakit tanpa kasir", karena memang tidak menyediakan

\footnotetext{
${ }^{36} \mathrm{http}: / /$ pusat.baznas.go.id/zakat-saham-dan-obligasi/ diakses tanggal 29 Nopember 2013

${ }^{37} \mathrm{http}: / /$ pusat.baznas.go.id/profil/ diakses tanggal 29 Nopember 2013
} 
kasir pembayaran alias gratis. Rumah Sehat Baznas hanya dikhususkan untuk masyarakat miskin secara gratis dengan menggunakan sistem membership.

4. Rumah Cerdas Anak Bangsa:

Adalah program pendanaan dan bimbingan bagi siswa dan mahasiswa dalam bidang pendidikan dan pelatihan sehingga menjadi individu yang mandiri.

5. Baitul Qiradh Baznas:

Adalah lembaga keuangan mikro syariah berbadan hukum koperasi yang menyalurkan dana ZIS secara produktif baik melalui pinjaman kebajikan (Al Qardhul Hasan) maupun melalui pembiayaan dengan pola syariah kepada para mustahik.

6. Program Tanggap Bencana:

Adalah program merespon untuk memberikan bantuan kepada masyarakat yang tertimpa musibah sesaat setelah terjadi bencana.

7. Kaderisasi 1000 Ulama:

Adalah program peningkatan jenjang pendidikan (penambahan ilmu) bagi ulama yang sudah bergerak di masyarakat. Program dengan sistem seleksi yang ketat ini bertujuan melahirkan ulama yang mampu menjawab seluruh permasalahan umat terkini. Program yang bekerjasama dengan Dewan Dakwah Islam Indonesia (DDII) ini melakukan seleksi ketat untuk para peserta program. Peserta yang dinyatakan lulus akan menempuh pendidikan S2/S3, diharapkan setelah lulus program magister/doktoral akan melaksanakan kegiatan penelitian, tulisan untuk membina masyarakat dan mengcounter perkembangan pemikiran yang menyimpang dari Al-Qur'an dan sunah. Setiap tahun akan menghasilkan 100 ulama, yang akan mengajar di perguruan tinggi Islam dan terlibat pada aktifitas dakwah.

\section{G. Layanan BAZNAS}

BAZNAS saat ini sudah memiliki layanan-layanan sebagai berikut:

1. Zakat Via Payroll System

Adalah sebuah bentuk pelayanan zakat melalui pemotongan langsung dari gaji seorang karyawan di sebuah perusahaan.

2. Zakat Via Mobil Zakat Keliling

BAZNAS memiliki sarana 1 unit Mobil Zakat Keliling, donasi dari Bank Mega Syariah, yang secara periodik ditempatkan di beberapa lokasi strategis guna memudahkan muzaki melakukan pembayaran ZIS nya.

3. Zakat Via E-Card

BAZNAS bekerjasama dengan kalangan perbankan, menyediakan fasilitas pembayaran melaui menu pembayaran zakat di ATM. Di masa depan, BAZNAS akan menerbitkan kartu Nomor Pokok Wajib Zakat (NPWZ) yang sekaligus dapat berfungsi sebagai kartu Debit dan ATM, serta E-Wallet. Selain untuk pembayaran, data muzaki dan data history pembayaran zakat muzaki dapat diunduh ke dalam kartu elektronik tersebut untuk memudahkan para muzaki dalam menunaikan kewajiban zakatnya dimana saja dan kapan saja.

4. Zakat Via Online Payment

Perkembangan teknologi web 2.0 semakin membuat semarak proses transaksi online melalui portal, web dan blog di internet secara mudah, aman dan cepat. BAZNAS menyediakan kemudahan layanan pembayaran zakat, infak shadaqoh dan donasi lain melalui mekanisme online payment atau e-payment dengan bekerjasama dengan pihak perbankan syariah dan konvensional.

5. Zakat via Perbankan Syariah 
BAZNAS bekerjasama dengan kalangan perbankan, menyediakan fasilitas pembayaran melaui menu pembayaran zakat di ATM.

6. Zakat Via Konter

Salah satu upaya BAZNAS untuk memberikan kemudahan bagi masyarakat untuk membayarkan ZIS di antaranya adalah dengan Konter Layanan Zakat, Infaq, dan Shodaqoh (ZIS). Tujuan dari pelayanan konter ini adalah agar para muzaki mendapatkan pelayanan yang lebih dekat dan eksklusif, tidak hanya untuk membayarkan zakat, akan tetapi untuk berkonsultasi seputar ZIS serta informasi lengkap mengenai program BAZNAS.

7. Unit Pengumpul Zakat (UPZ)

Dalam melaksanakan tugas dan fungsinya, BAZNAS, BAZNAS provinsi, dan BAZNAS kabupaten/kota dapat membentuk UPZ pada instansi pemerintah, badan usaha milik negara, badan usaha milik daerah, perusahaan swasta, dan perwakilan Republik Indonesia di luar negeri serta dapat membentuk UPZ pada tingkat kecamatan, kelurahan atau nama lainnya, dan tempat lainnya.

\section{H. Layanan Online Muzaki}

BAZNAS sudah memiliki website yaitu dengan alamat http://www.baznas.go.id atau http://pusat.baznas.go.id (seperti Gambar 1) dan sejak tahun 2012 sudah memiliki sistem zakat online untuk para muzaki, layanan online yang diberikan kepada muzaki (seperti Gambar 2) dan dapat diakses dari halaman depan website BAZNAS.

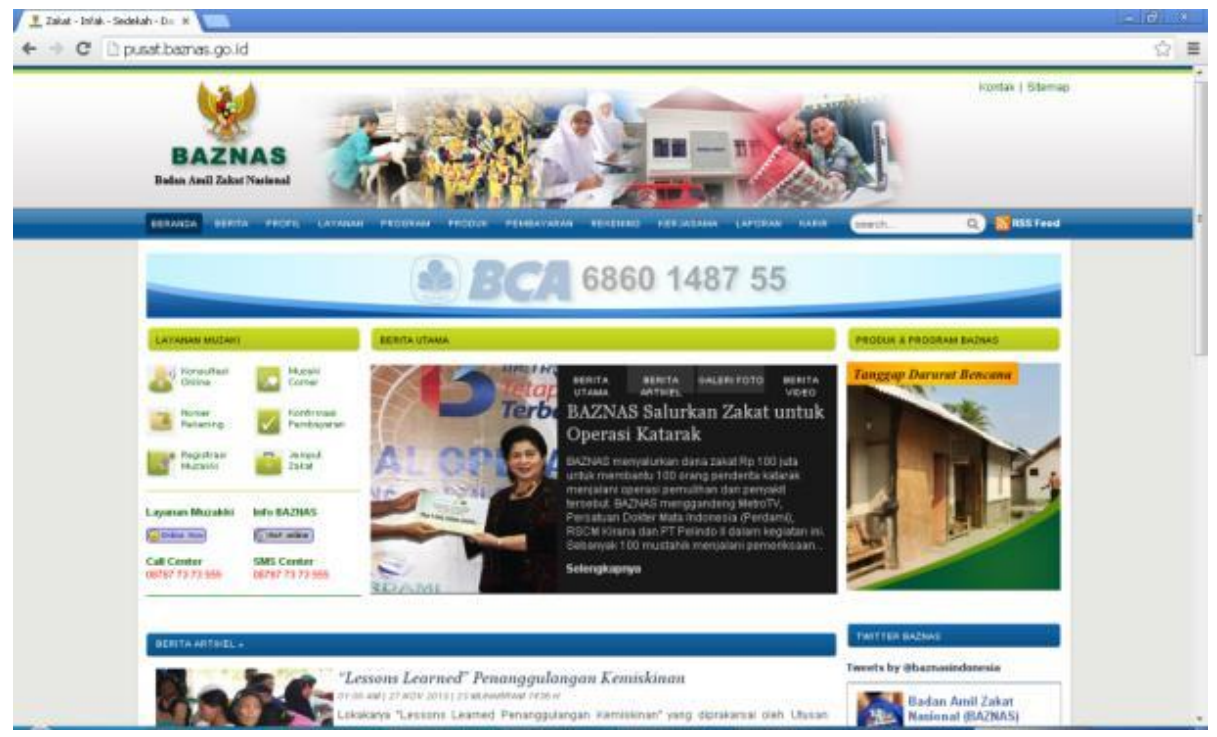

Gambar 1. Website BAZNAS 


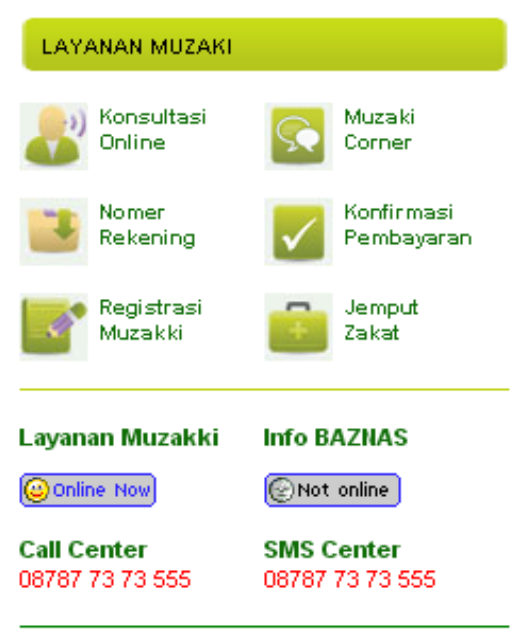

Gambar 2. Menu Layanan Muzaki

\section{Registrasi Online Muzaki}

Registrasi online digunakan untuk mendaftarkan diri sebagai muzaki dan mendapatkan Nomor Pokok Wajib Zakat (NPWZ). Untuk melakukan registrasi online para calon muzaki harus melalui tahap-tahap sebagai berikut:

a) Membuka website BAZNAS (Gambar 1)

b) Mengklik menu Registrasi Muzaki pada menu layanan muzaki (Gambar 2)

c) Kemudian muncul tampilan seperti Gambar 3 . 


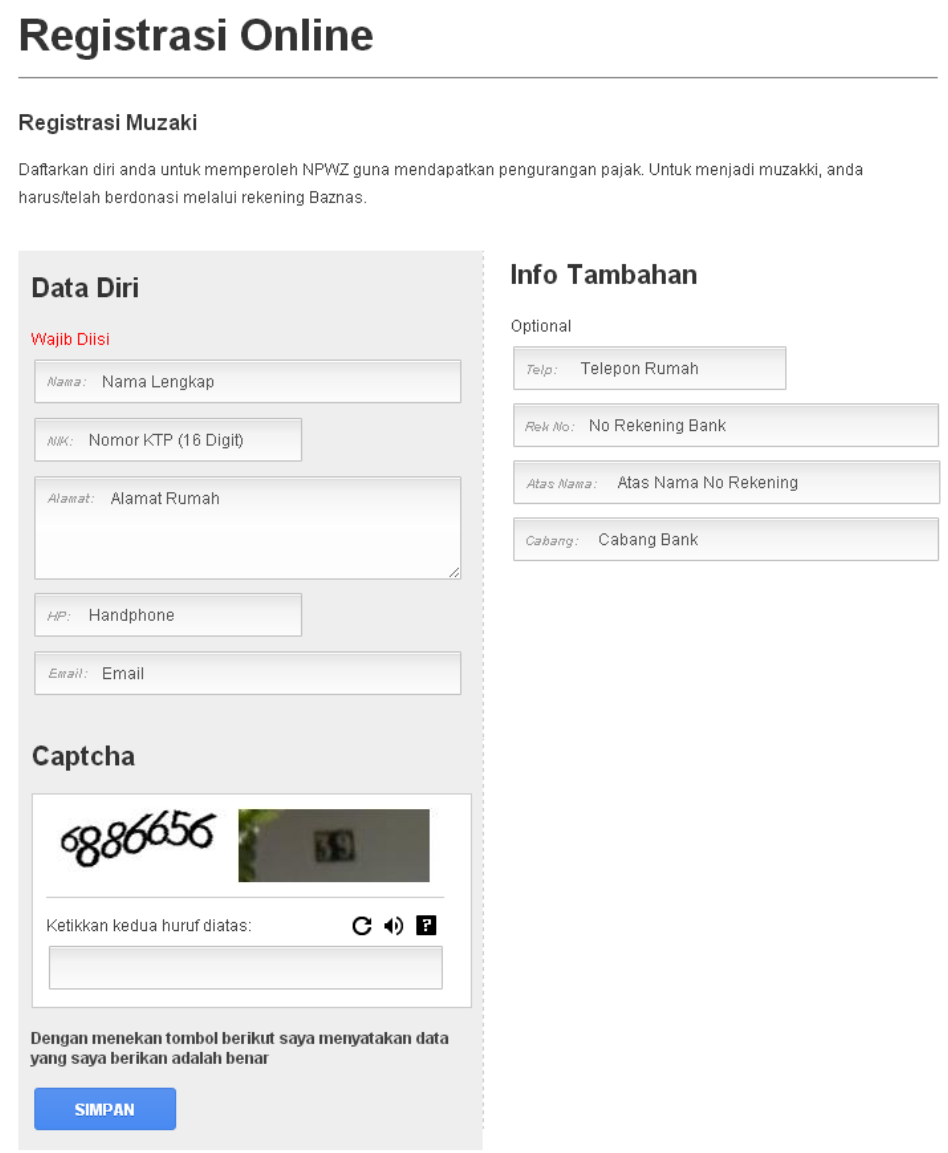

Gambar 3. Registrasi Online

d) Calon muzaki wajib memasukan data pribadi dengan benar seperti nama lengkap, nomor KTP, alamat rumah, nomor handphone dan email. Sedangkan info tambahan seperti telepon rumah, nomor rekening bank, rekening atas nama dan cabang bank hanya sebagai isian opsional (tidak wajib).

e) Setelah selesai input data diri, calon muzaki harus memasukan kode atau angkaangka captcha sebagai kode pengamanan registrasi dan tekan tombol simpan.

f) Berarti proses registrasi sudah selesai dan informasi registrasi langsung terkirim ke email calon muzaki. Di dalam email tersebut diberitahukan bahwa untuk mendapatkan NPWZ butuh waktu kurang lebih satu sampai tiga hari kerja.

g) Tetapi jika calon muzaki ingin cepat mendapatkan NPWZ sebaiknya dibalas (replay) email tersebut pada jam kerja dan disebutkan alasan bahwa akan membayar zakat dan cantumkan atau lampirkan informasi registrasi yang telah diberikan dalam email tersebut.

h) Kemudian dalam selang waktu tidak lama calon muzaki akan mendapatkan email balasan berupa NPWZ dan password untuk login ke sistem zakat online.

\section{Metode Pembayaran Zakat Online BAZNAS}

Dalam melakukan pembayaran zakat melalui BAZNAS, para muzaki dapat melakukan beberapa metode yaitu antara lain:

a) Transfer atau kliring melalui kounter bank ke rekening BAZNAS.

b) Transfer melalui mesin ATM ke rekening BAZNAS.

c) Transfer melalui menu Pembayaran>ZIS pada menu ATM bank syariah.

d) Transfer menggunakan fasilitas Internet Banking atau $e$-Banking. 
Semua metode di atas harus mempunyai bukti transfer, supaya nantinya bukti transfer tersebut dapat dijadikan sebagai lampiran untuk mendapatkan laporan zakat. Laporan zakat tersebut dapat digunakan sebagai pengurangan pembayaran pajak. Jika muzaki mentransfer zakat melalui kounter bank atau mesin ATM para muzaki harus menscan bukti transfer dengan scanner atau difoto dan disimpan dalam bentuk file. Sebaiknya muzaki melakukan transfer melalui Internet Banking, karena tidak perlu lagi menscan atau memfoto bukti transfer karena bukti transfernya bisa disimpan langsung dalam bentuk file.

Para muzaki dapat membayar zakatnya melalui rekening BAZNAS jika menggunakan metode pembayaran pertama, kedua atau keempat. Rekening zakat BAZNAS terdapat pada beberapa bank baik bank konvensional maupun bank syariah seperti Tabel 1 di bawah ini:

Tabel 1. Rekening Zakat BAZNAS ${ }^{38}$

\begin{tabular}{|c|c|c|c|c|c|}
\hline No & Nama Bank & Rekening Zakat & No & Nama Bank & Rekening Zakat \\
\hline 1. & mandırı & 070-00-0185555-5 & 13. & 用 BTN 占拦遂 & 7011001155 \\
\hline 2. & $\begin{array}{l}\text { mandırı } \\
\text { Syarlah }\end{array}$ & 7001325498 & 14. & $\underset{\text { syariah }}{\text { BLI }}$ & 701311637555 \\
\hline 3. & Danamon & 0029285558 & 15. & $\begin{array}{l}\text { NGBNI } \\
\text { SYARIAH }\end{array}$ & 0988888819 \\
\hline 4. & $\overrightarrow{\text { Danamon }}$ & 0058332362 & 16. & bilỉsyariah & $2-700-005554$ \\
\hline 5. & \& BCA & 6860148755 & 17. & 9 OCBC NISP & 127.80 .0001 .555 \\
\hline 6. & PE BANK MUAMALAT & 3010070753 & 18. & $\begin{array}{r}\text { Syariah } \\
\text { SyMIAGA }\end{array}$ & 502.01 .00118 .00 .9 \\
\hline 7. & bilisyariah & $2-700-000555$ & 19. & (2) sinarmas & 9900023828 \\
\hline 8. & $\begin{array}{l}\text { NGBNI } \\
\text { SYARIAH }\end{array}$ & 0095555554 & 20. & BANK & 006.01.01.00555.5 \\
\hline 9. & $\underset{\substack{\text { PermataBank } \\
V y}}{\nabla / p}$ & 971006455 & 21. & bank r̊victoria & 500.100 .555 .3 \\
\hline 10. & BANKODKI & 7017000755 & 22. & BCASYARIAH & $011-555510$ \\
\hline 11. & BANK BUKOPIN & 8800255-01-6 & 23. & Rekening Ponsel & 08100000111 \\
\hline 12. & 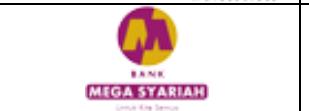 & $\begin{array}{l}1000010000 \\
15559\end{array}$ & & & \\
\hline
\end{tabular}

\section{Login Muzaki (Muzaki Corner)}

Login muzaki digunakan untuk para muzaki jika ingin masuk kedalam sistem online zakat BAZNAS. Untuk login, muzaki bisa melakukan tahap-tahap sebagai berikut:

a) Masuk dari halaman utama website BAZNAS (Gambar 1).

b) Klik menu Muzaki Corner pada menu Layanan Muzaki (Gambar 2).

c) Muncul tampilan halaman login untuk muzaki (Gambar 4).

\footnotetext{
${ }^{38}$ http://pusat.baznas.go.id/rekening-baznas-2/ diakses pada tanggal 30 Nopember 2013
} 
d) Untuk login muzaki harus ada NPWZ dan password.

e) Masukan NPWZ pada isian NPWZ dan password pada isian password.

f) Klik tombol submit.

g) Setelah masuk, maka akan tampil halaman muzaki corner (Gambar 5).

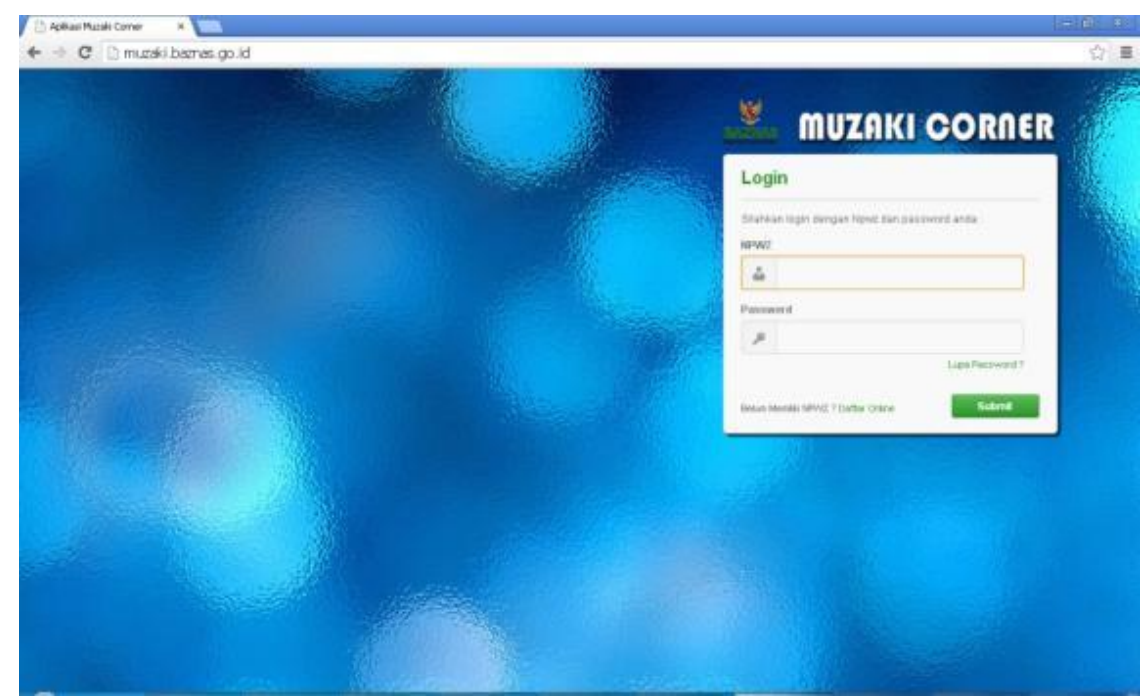

Gambar 4. Halaman Login

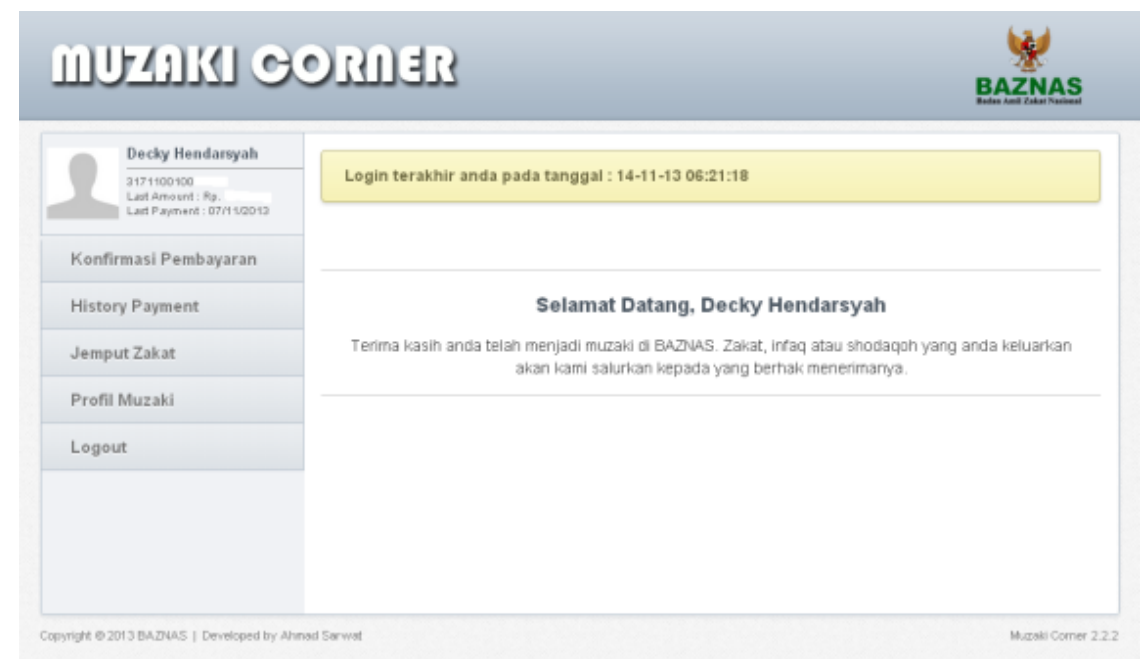

Gambar 5. Halaman Muzaki Corner

\section{Profil Muzaki}

Profil muzaki digunakan untuk melihat atau mengedit data pribadi muzaki (Gambar 6) seperti Nomor Induk Kependudukan (NIK), alamat, telepon, handphone, fax, email, tempat lahir, tanggal lahir, golongan darah, pendidikan, pekerjaan dan alamat kantor. Untuk mengedit data-data tersebut muzaki tinggal klik gambar pensil yang ada disamping data-data tersebut dan edit data yang ada. Kemudian jika muzaki ingin mengganti password tinggal diklik menu Ubah Password pada bagian atas kanan profil muzaki (lihat Gambar 6). Setelah itu masukan password baru dua kali dan simpan. 


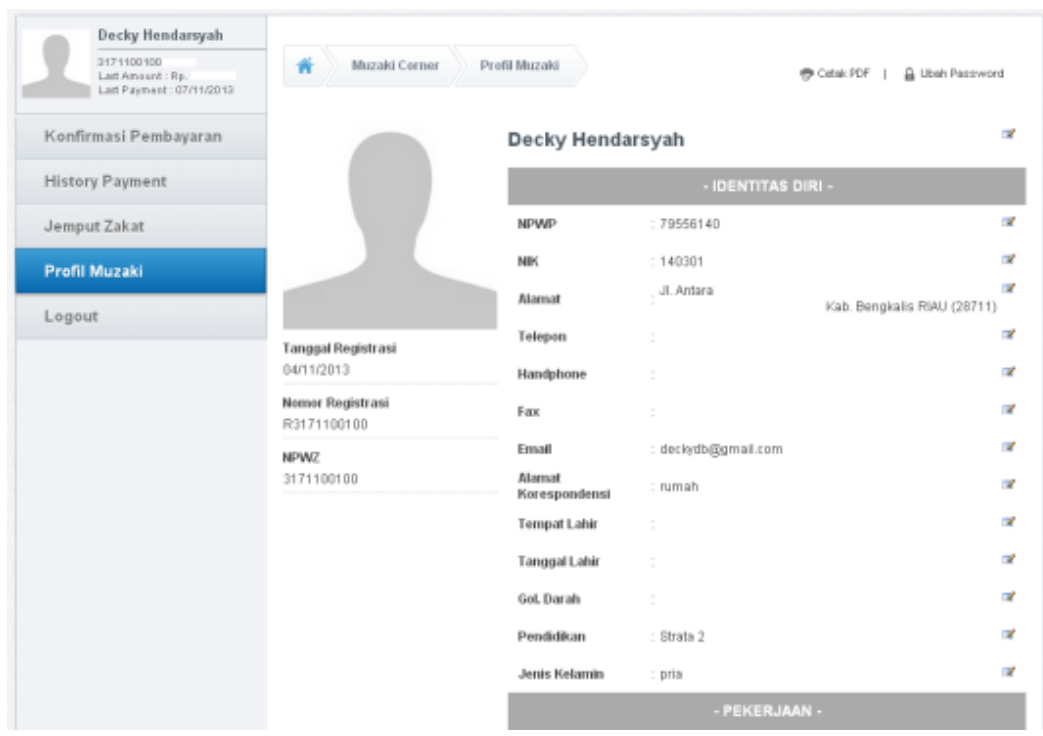

Gambar 6. Profil Muzaki

\section{Konfirmasi Pembayaran Zakat}

Konfirmasi pembayaran zakat bisa dilakukan dengan dua cara yaitu:

a) Tanpa login, tahap-tahapnya adalah sebagai berikut:

- Masuk ke halaman utama website BAZNAS (Gambar 1).

- Klik menu Konfirmasi Pembayaran pada menu Layanan Muzaki (Gambar 2).

- Tampilan halaman konfirmasi (Gambar 7).

- Masukan data Nama, NPWZ, Handphone dan Email.

- Masukan tanggal pembayaran zakat.

- Pilih bank tujuan pembayaran zakat.

- Pilih cara pembayaran, apakah menggunakan ATM atau Intenet Banking.

- Pilih jenis pembayarannya apakah zakat, infaq atau infaq program.

- Masukan jumlah uang yang didonasikan.

- Pilih file bukti pembayaran atau transfer.

- Masukan keterangan dari donasi, misalnya: zakat profesi, infaq, sadaqah dan lain-lain.

- Masukan kode captcha untuk keamanan keamanan transaksi.

- Klik tombol simpan.

- Konfirmasi pembayaran sudah selesai.

- Jika konfirmasi sudah di acc oleh admin BAZNAS maka status konfirmasi berubah menjadi "completed". Kemudian muzaki akan mendapat email dan sms pemberitahuan bahwa konfirmasi pembayaran zakat sudah diterima.

b) Melalui login, tahap-tahapnya adalah sebagai berikut:

- Masuk dari halaman utama website BAZNAS (Gambar 1).

- Klik menu Muzaki Corner pada menu Layanan Muzaki (Gambar 2).

- Lakukan login.

- Setelah masuk ke halaman muzaki corner (Gambar 5), klik menu Konfirmasi Pembayaran.

- Tampil data-data konfirmasi pembayaran (Gambar 8).

- Klik tombol Registrasi Baru pada bagian atas data-data konfirmasi pembayaran

- Muncul halaman konfirmasi (Gambar 9). 
- Masukan tanggal pembayaran zakat.

- Pilih bank tujuan pembayaran zakat.

- Pilih cara pembayaran, apakah menggunakan ATM atau Intenet Banking.

- Pilih jenis pembayarannya apakah zakat, infaq atau infaq program.

- Masukan jumlah uang yang didonasikan.

- Masukan keterangan dari donasi, misalnya: zakat profesi, infaq, sadaqah dan lain-lain.

- Pilih file bukti pembayaran atau transfer.

- Klik tombol simpan.

- Konfirmasi pembayaran sudah selesai.

- Kemudian data konfirmasi akan tampil pada record konfirmasi dengan status "submitted" atau menunggu acc dari admin BAZNAS.

- Ketika konfirmasi sudah melalui tahap verifikasi (proses) maka muzaki akan dapat email pemberitahuan.

- Jika konfirmasi sudah di acc oleh admin BAZNAS maka status konfirmasi berubah menjadi "completed". Kemudian muzaki akan mendapat email dan sms pemberitahuan bahwa konfirmasi pembayaran zakat sudah diterima.

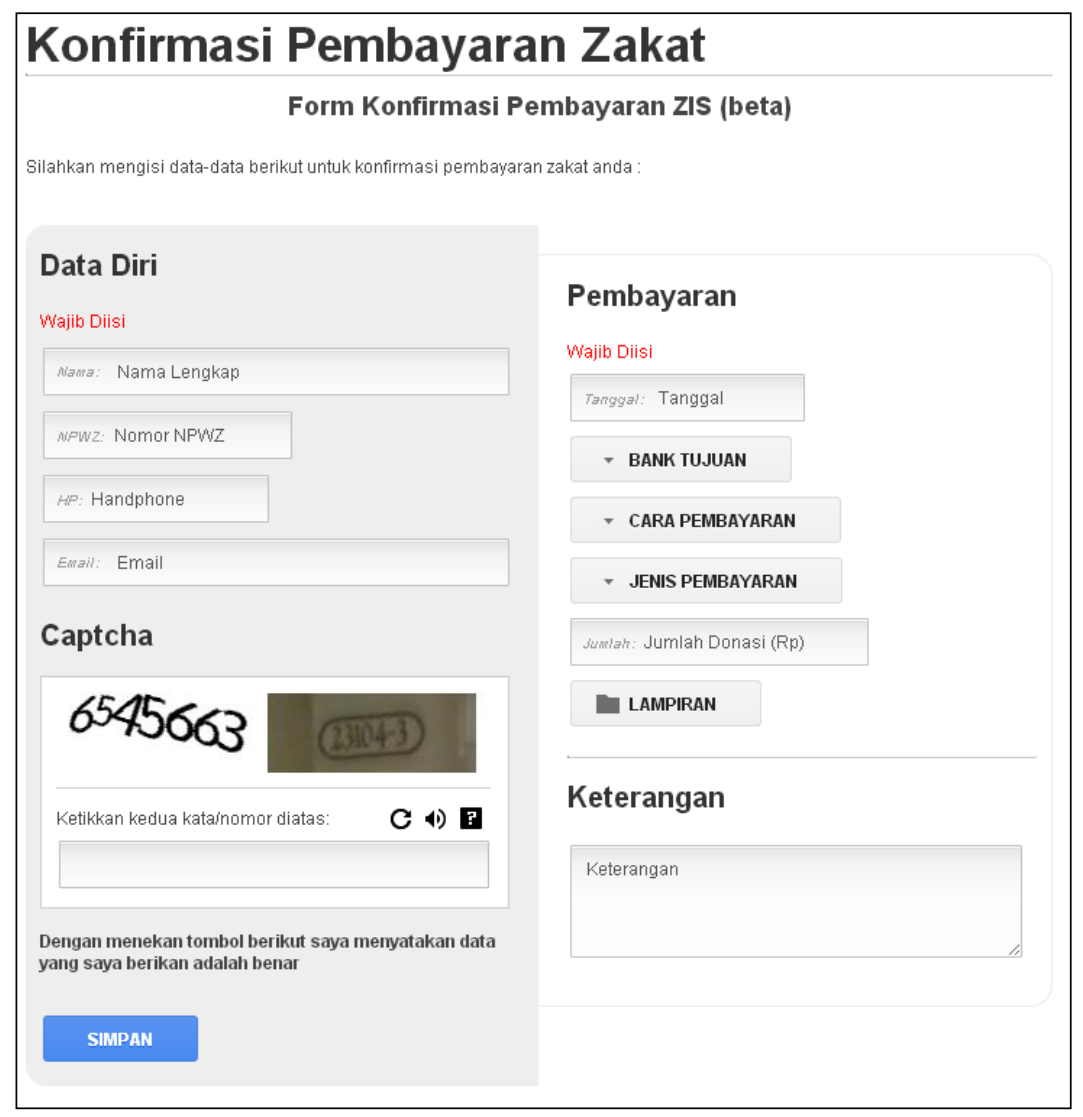

Gambar 7. Konfirmasi Pembayaran Zakat Tanpa Login 


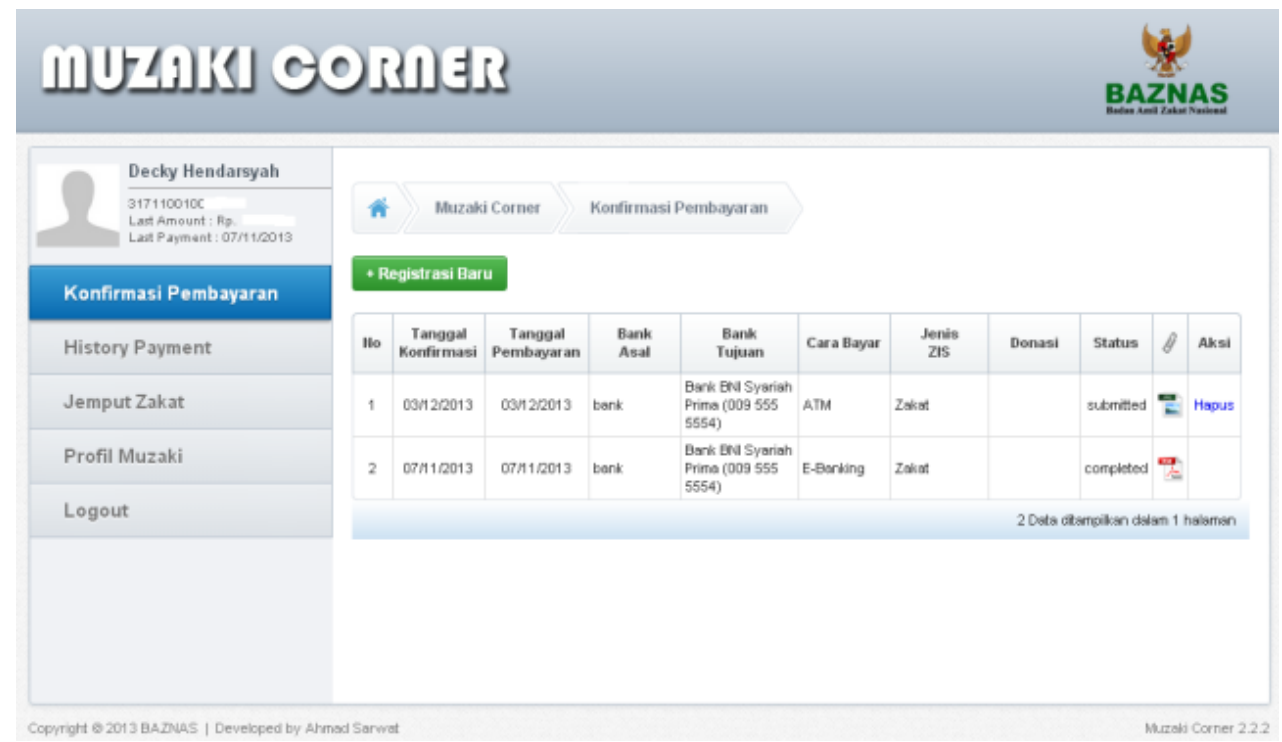

Gambar 8. Konfirmasi Pembayaran

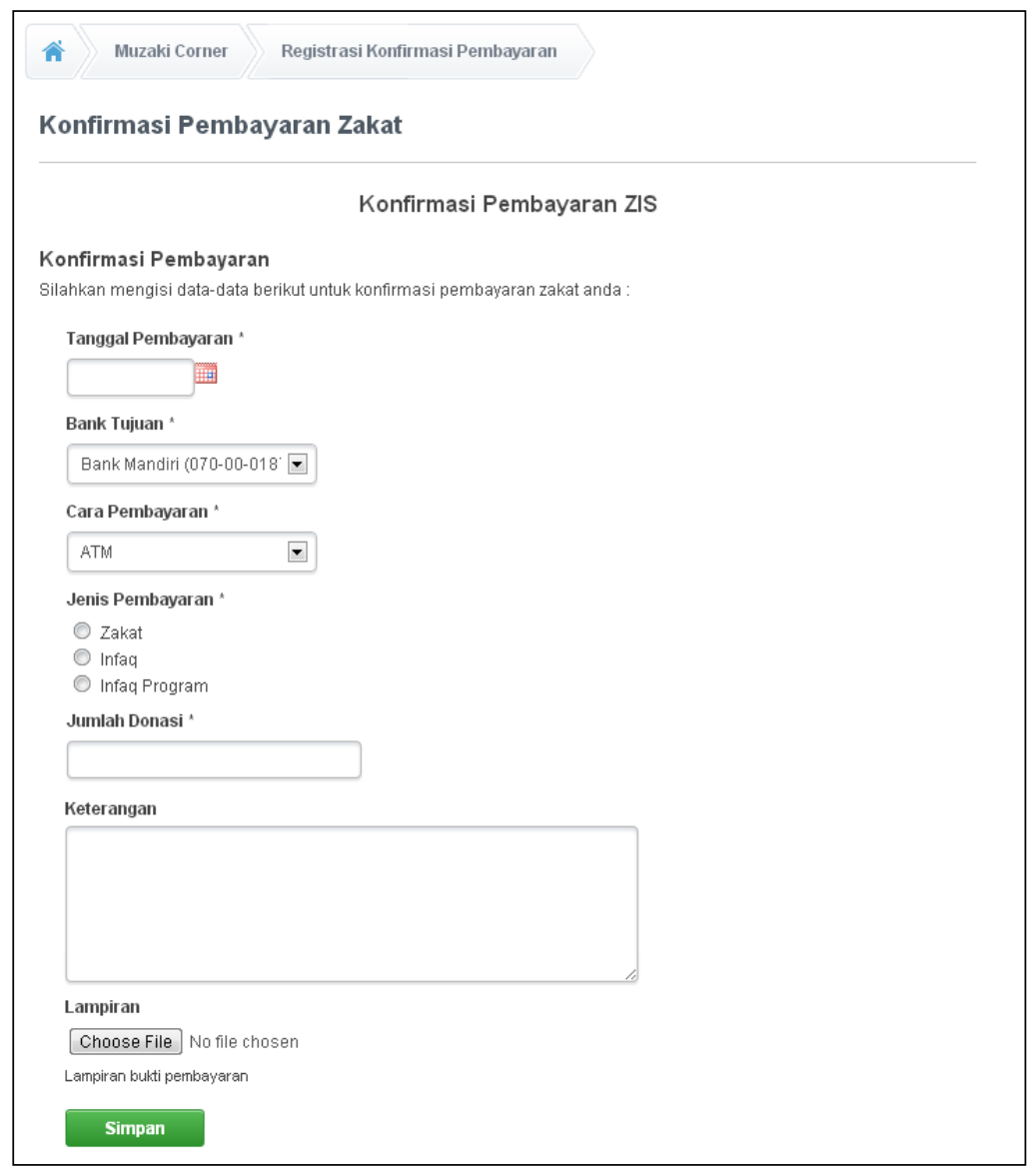

Gambar 9. Konfirmasi Pembayaran Zakat Dengan Login

\section{History Pembayaran Zakat}

History pembayaran zakat merupakan hasil laporan bahwa pembayaran zakat sudah diterima oleh pihak BAZNAS. Laporan tersebut bisa dicetak sebagai bukti untuk pengurangan pajak. Untuk mencetak laporan pembayaran zakat tahap-tahap yang harus dilakukan adalah sebagai berikut: 
a) Masuk dari halaman utama website BAZNAS (Gambar 1).

b) Klik menu Muzaki Corner pada menu Layanan Muzaki (Gambar 2).

c) Lakukan login.

d) Setelah masuk ke halaman muzaki corner, klik menu History Payment.

e) Tampil data-data history pembayaran zakat (Gambar 10).

f) Jika muzaki ingin mencetak laporan zakat pertransaksi, tinggal klik link Cetak pada transaksi bersangkutan dan tampil laporan zakat pertransaksi (Gambar 11).

g) Jika muzaki ingin mencetak laporan zakat perperiode, masukan periode mulai dari tanggal tertentu sampai tanggal yang diinginkan. Kemudian tampil data-data history pembayaran zakat sesuai dengan periode yang dimasukan, setelah itu tinggal klik tombol Cetak Laporan Donasi yang berada dibawah data. Kemudian akan tampil laporan zakat perperiode (multi transaksi) (Gambar 12).

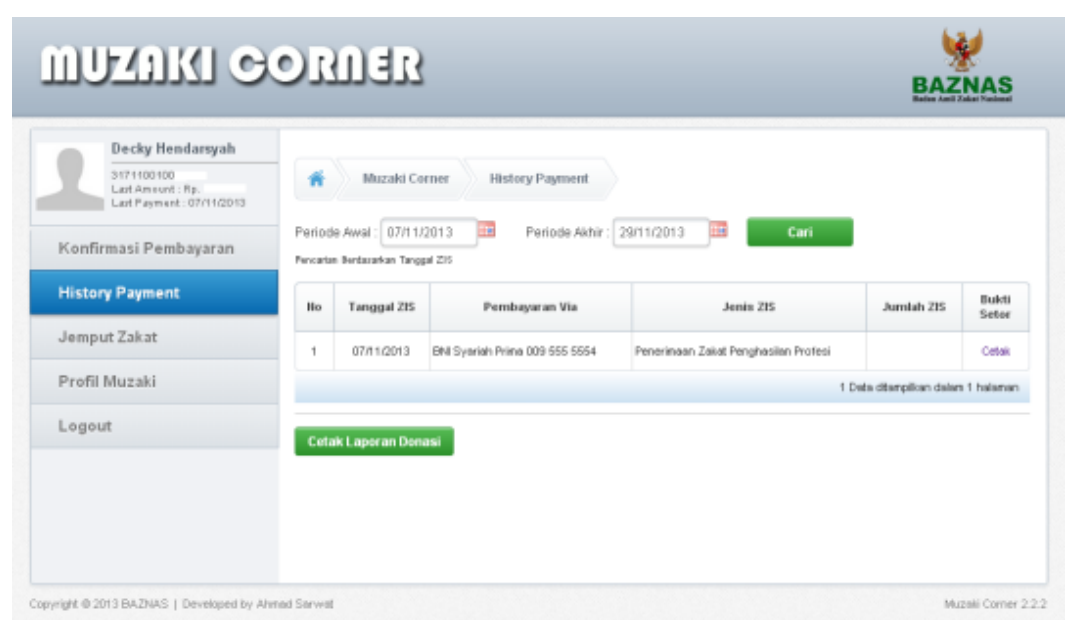

Gambar 10. History Payment 


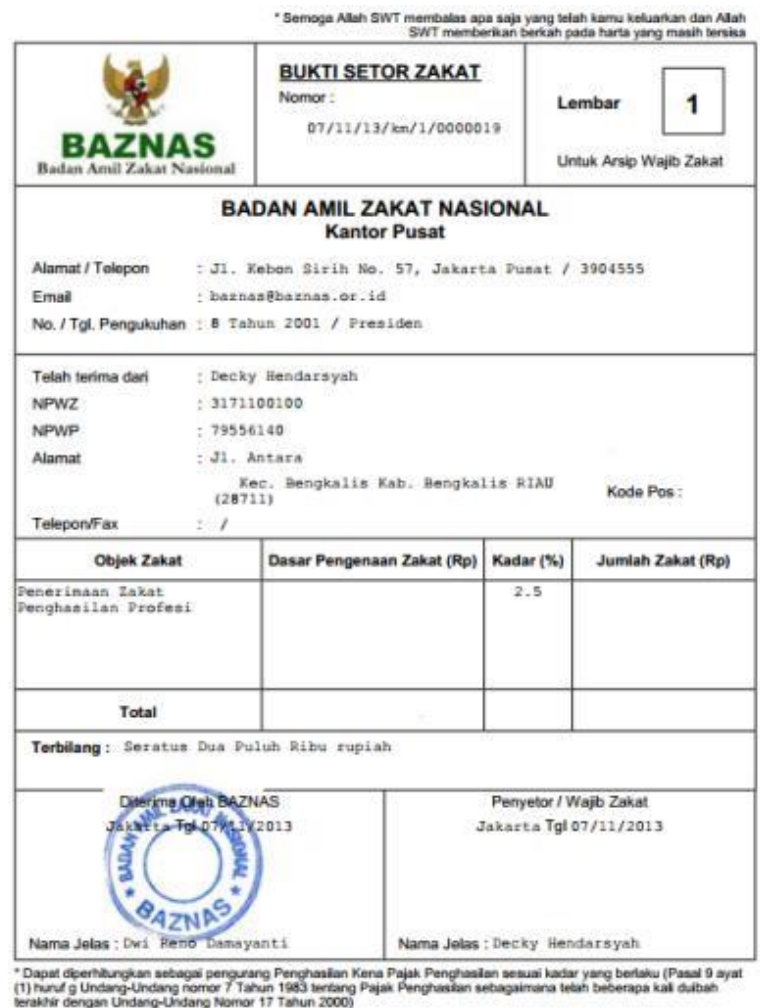

Gambar 11. Bukti Setor Zakat Pertransaksi

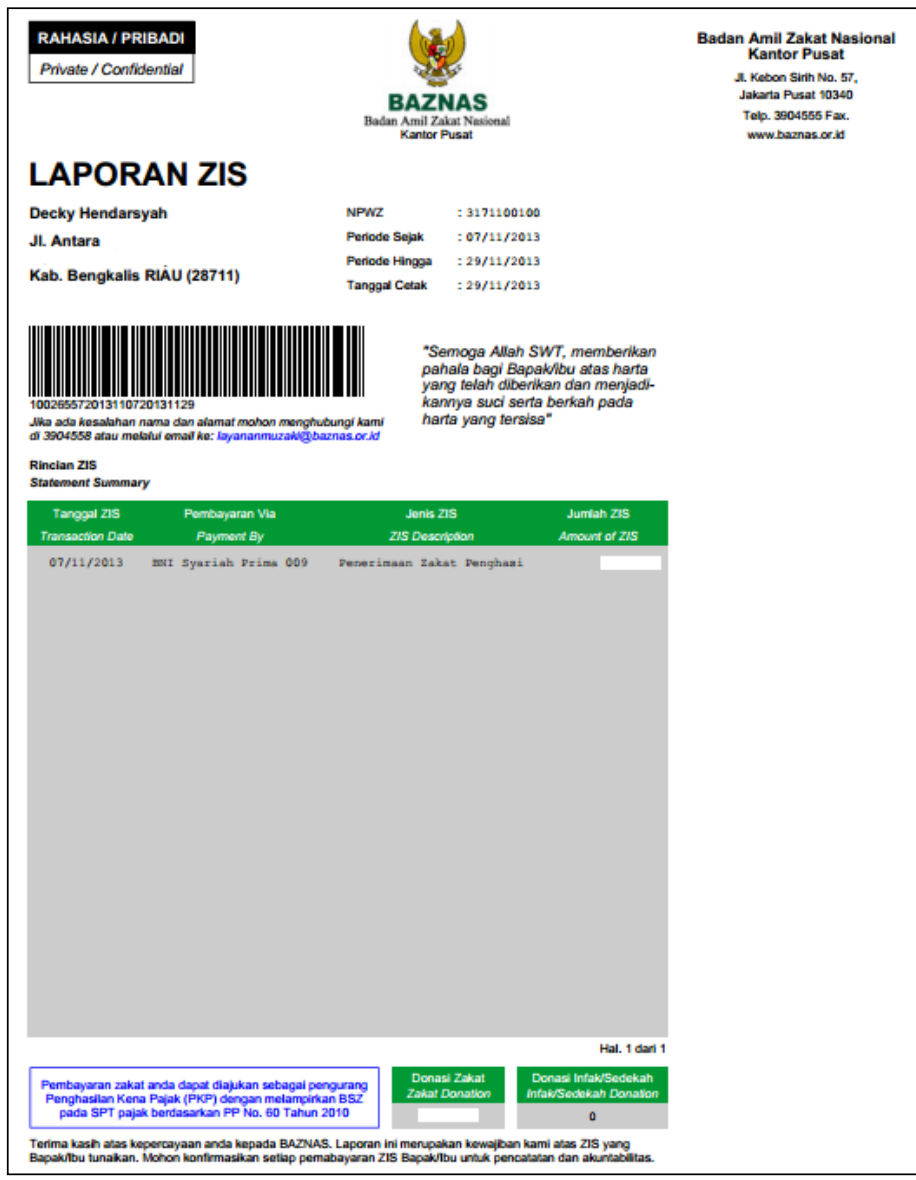

Gambar 12. Bukti Setor Zakat Perperiode (Multi Transaksi) 


\section{Jemput Zakat}

Jemput zakat merupakan salah satu layanan dari BAZNAS untuk mempermudah muzaki dalam membayar zakat, infaq dan sadaqah. Maksud jemput zakat disini muzaki meminta kepada pihak BAZNAS supaya bisa dijemput uang pembayaran zakat sesuai dengan alamat dan waktu yang diinginkan oleh muzaki. Zakat yang akan dijemput oleh pihak BAZNAS harus minimal Rp. 1.000.000,-. Untuk mengakses layanan jemput zakat bisa dilakukan dengan dua cara yaitu tanpa login dan melalui login.

a) Jemput zakat tanpa login, tahap-tahapnya adalah sebagai berikut:

- Masuk ke halaman utama website BAZNAS (Gambar 1).

- Klik menu Jemput Zakat pada menu Layanan Muzaki (Gambar 2).

- Tampilan halaman jemput zakat (Gambar 13).

- Masukan informasi data muzaki seperti: Nama Lengkap, No. HP, NPWZ, Email, Jumlah Donasi, Tanggal Penjemputan, Jenis Donasi dan Alamat.

- Masukan kode captcha untuk keamanan transaksi.

- Klik tombol Submit.

- Kemudian muzaki tinggal tunggu dihubungi pihak BAZNAS untuk dijemput zakatnya.

b) Jemput zakat melalui login, tahap-tahapnya adalah sebagai berikut:

- Masuk ke halaman utama website BAZNAS (Gambar 1).

- Klik menu Muzaki Corner pada menu Layanan Muzaki (Gambar 2).

- Lakukan login.

- Setelah masuk ke halaman muzaki corner (Gambar 5), klik menu Jemput Zakat.

- Tampil halaman jemput zakat (Gambar 14).

- Pilih jenis donasi dan besar donasi.

- Pilih alamat penjemputan, jika ingin alamat yang berbeda dari alamat rumah atau alamat kantor, pilih alamat lain dan masukan alamat lain tersebut.

- Jika ada keterangan lain masukan keterangan yang diinginkan.

- Klik tombol simpan.

- Kemudian muzaki tinggal tunggu dihubungi pihak BAZNAS untuk dijemput zakatnya. 


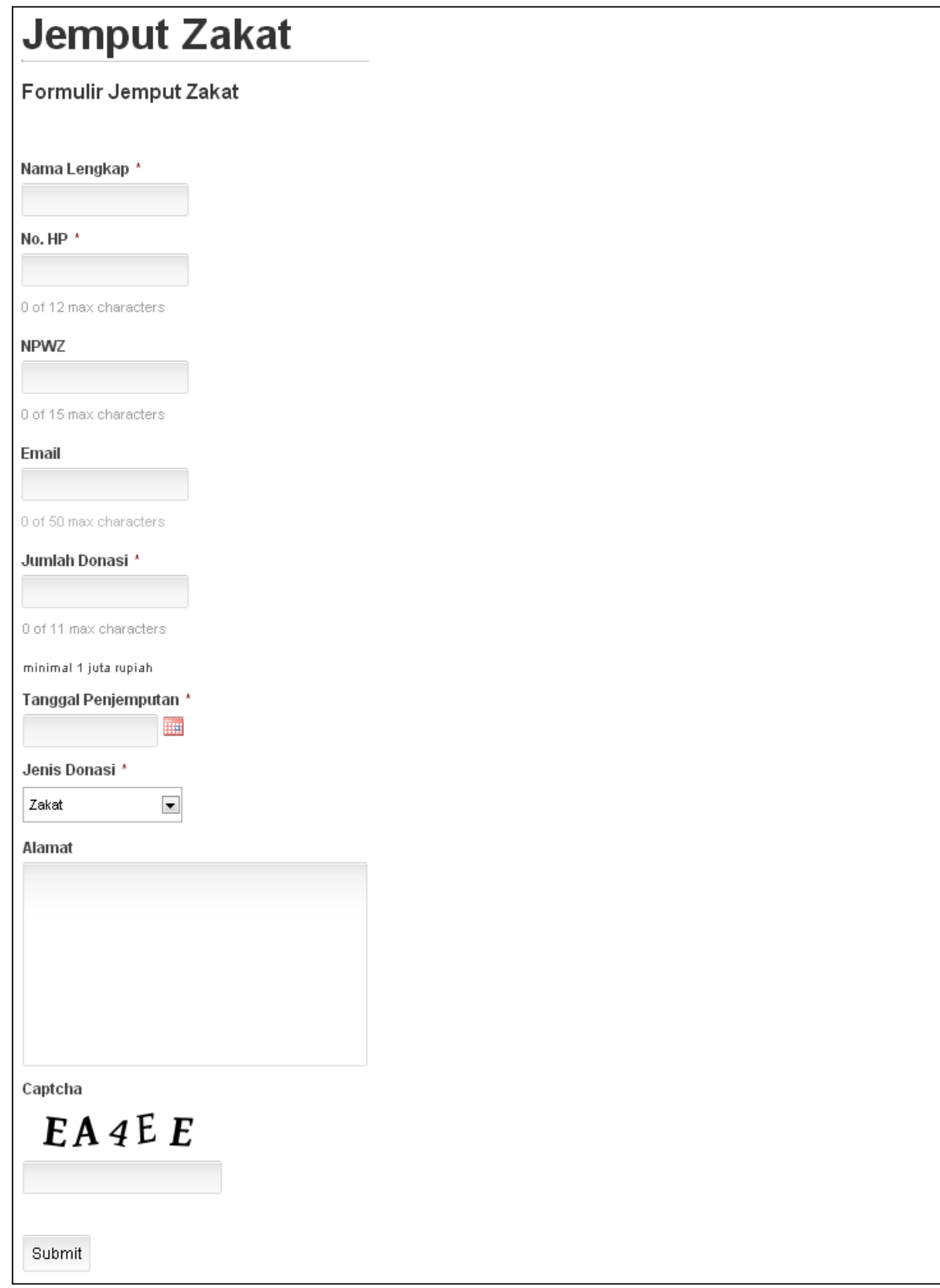

Gambar 13. Jemput Zakat Tanpa Login 


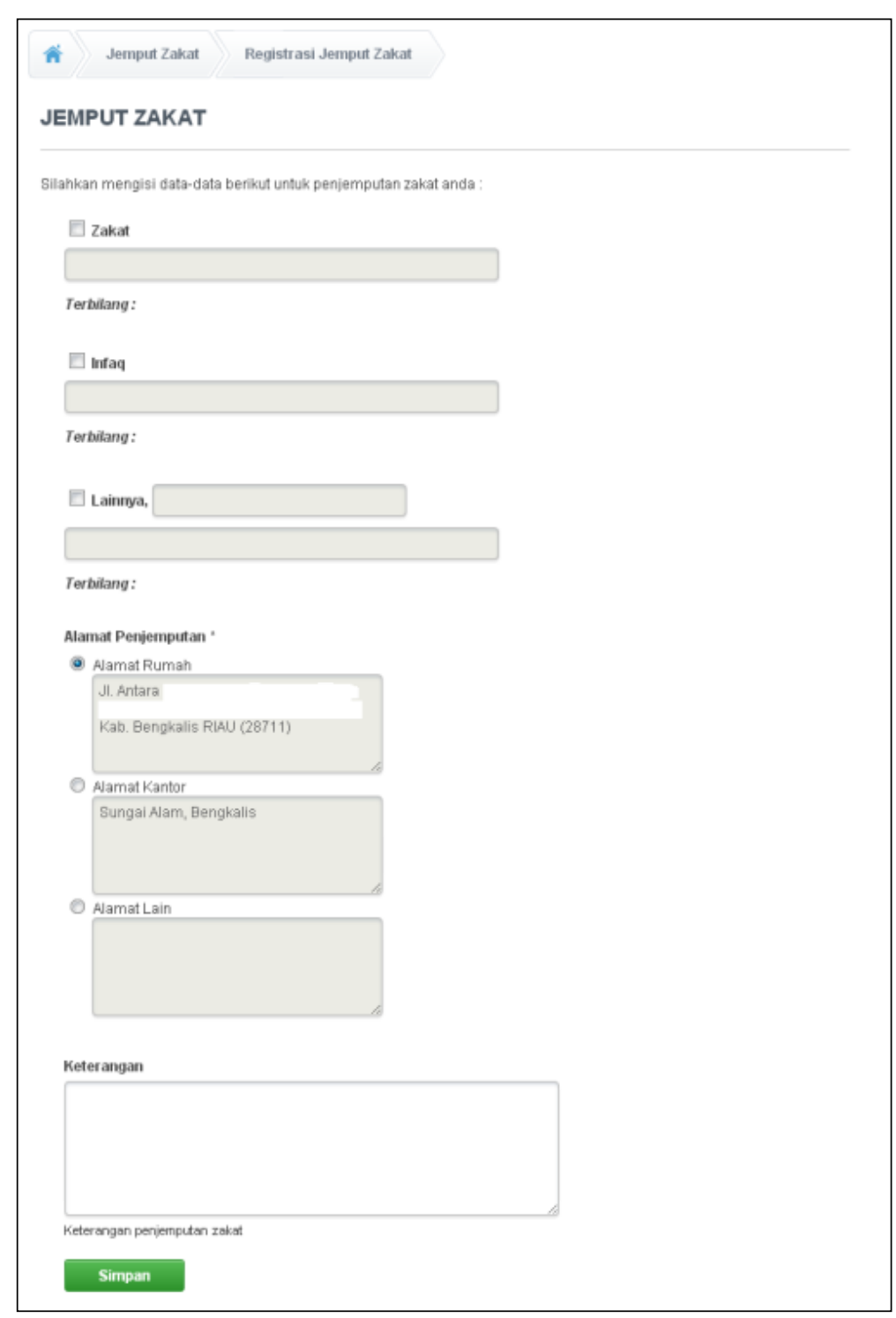

Gambar 14. Jemput Zakat Melalui Login

\section{Konsultasi Online}

Konsultasi online merupakan salah satu layanan BAZNAS yang bertujuan agar dapat menjalin silahturahmi antara BAZNAS dengan masyarakat. Pada konsultasi online ini pihak BAZNAS membuka kesempatan kepada masyarakat agar dapat berkontribusi untuk bertanya seputar zakat, infaq dan sadaqah. Untuk melakukan konsultasi online tahap-tahap yang harus dilakukan adalah sebagai berikut:

a) Masuk ke halaman utama website BAZNAS (Gambar 1).

b) Klik menu Konsultasi Online pada menu Layanan Muzaki (Gambar 2).

c) Tampilan halaman konsultasi online (Gambar 15).

d) Masukan Nama, Email, Alamat dan Pertanyaan.

e) Masukan kode captcha untuk keamanan transaksi.

f) Klik tombol kirim

g) Tunggu email masuk sebagai jawaban dari pertanyaan yang dikirimkan. 


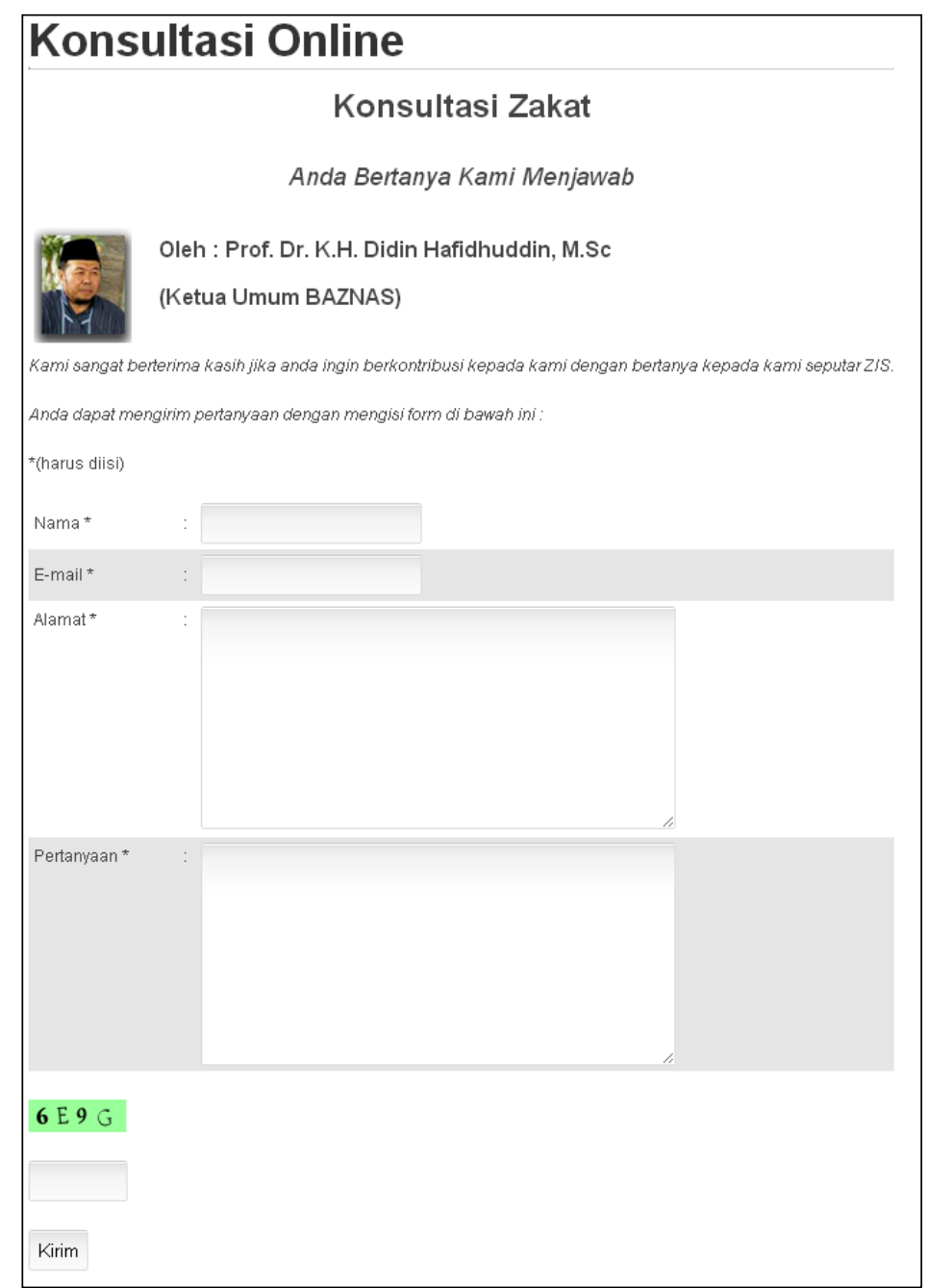

Gambar 15. Konsultasi Online

\section{Manfaat Zakat Online BAZNAS}

Manfaat zakat online BAZNAS bagi para muzaki adalah sebagai berikut:

1. Muzaki tidak perlu lagi datang ke kantor BAZNAS untuk membayar zakat, infaq dan sadaqah.

2. Muzaki yang melakukan perjalanan keluar daerah atau luar negeri dapat membayar zakat selama masih ada koneksi Internet.

3. Muzaki secara tidak langsung pembayaran zakatnya sudah terkelola dan tersimpan dalam database.

4. Muzaki bisa mencetak laporan pembayaran zakat sendiri dan dapat digunakan sebagai lampiran pemotongan pajak.

5. Muzaki juga dimudahkan dengan adanya fasilitas jemput zakat.

6. Masyarakat bisa berkonsultasi dengan BAZNAS seputar zakat, infaq dan sadaqah tanpa perlu datang ke kantor BAZNAS.

7. Sistem zakat online BAZNAS user friendly (mudah digunakan).

\section{J. Kelemahan Zakat Online BAZNAS}

Kelemahan zakat online BAZNAS adalah sebagai berikut:

1. Belum tersedianya zakat online dalam versi mobile. 
2. Ketika diakses menggunakan sistem operasi Android, tidak bisa melampirkan file bukti transfer pembayaran zakat.

3. Ketika diakses menggunakan sistem operasi Android, tidak bisa menyimpan file laporan pembayaran zakat.

\section{K. Penutup}

Sebagai penutup dari tulisan ini dapat ditarik kesimpulan dan saran sebagai berikut:

1. Zakat adalah kewajiban umat muslim yang harus dibayarkan jika harta kekayaannya sudah memenuhi nishab.

2. Bagi para muzaki sebaiknya menyalurkan zakat melalui lembaga amil zakat seperti BAZNAS.

3. Sistem zakat online sangat membantu para muzaki dalam menyalurkan zakat terutama bagi yang berada jauh dari kantor BAZNAS dan sedang melakukan perjalanan.

4. Laporan zakat bisa digunakan muzaki untuk mengurangi pembayaran pajak.

5. Sistem zakat online sebaiknya dikembangkan dalam versi mobile, sehingga akan lebih mempermudah muzaki dalam penggunaan sistem menggunakan smartphone atau tablet.

\section{Daftar Pustaka}

Abdurrahman Qadir, 1998, “Zakat Dalam Dimensi Mahdah dan Sosial”, Jakarta: PT. Raja Grafindo Persada.

Asnani, 2008, "Zakat Produktif Dalam Perspektif Hukum Islam”, Cetakan Pertama, Yogyakarta: Pustaka Pelajar.

David Whiteley, 2000, E-Commerce: Strategy, Technologies And Applications, London: MC. Graw-Hill.

Decky Hendarsyah, 2012, "Keamanan Layanan Internet Banking Dalam Transaksi Perbankan”, dalam jurnal Iqtishaduna, Vol. 1, No. 1, Juni 2012, Bengkalis.

Departemen Agama, 1998, "Alquran dan Terjemahan", Jakarta: CV-Atlas.

Fitrianto, 2012, "Program Lembaga Amil Zakat (LAZ) Swadaya Ummah Pekanbaru Dalam Membangun Kesejahteraan Umat”, dalam jurnal Iqtishaduna, Vol. 1, No. 1, Juni 2012, Bengkalis.

Heri Sudarsono, 2003, "Bank dan Lembaga Keuangan Syariah, Deskripsi dan Ilustrasi”, Edisi II, Cetakan III, Yogyakarta: Ekonosia.

http://pusat.baznas.go.id/. Diakses tanggal 29 Nopember sampai 3 Desember 2013.

Khadijah, 2012, "Zakat Dalam Sistem Ekonomi Islam Sebuah Alternatif Dalam Meningkatkan Kesejahteraan”, dalam jurnal Iqtishaduna, Vol. 1, No. 1, Juni 2012, Bengkalis.

Mahmood Shah dan Steve Clarke, 2009, E-Banking Management: Issue, Solutions and Strategies, London: IGI Global.

Mary J. Cronin, 1998, Banking and Finance on the Internet, Canada: John Wiley \& Sons.

Muhammad, 2002, "Zakat Profesi: Wacana Pemikiran Zakat Dalam Fiqqih Kontemporer", Jakarta: Salemba Empat.

M. Ali Hasan, 2006, "Zakat dan Infak Salah Satu Solusi Mengatasi Problema Sosial Indonesia”, Edisi 1, Cetakan 1, Jakarta: Kencana Prenada Group.

Nurdin M. Ali, 2006, "Zakat Sebagai Instrumen Dalam Kebijakan Fiskal”, Jakarta: PT. Raja Grafindo Persada.

Wahbah az-Zuhaili, 2011, Fiqh Islam wa Adillatuhu, Jilid 3, Terjemahan, Gema Insani. 
Yusuf Qardawi, 2002, "Hukum Zakat”, Cetakan Ketujuh, Jakarta: PT. Pustaka Litera Antarnusa. 